\title{
THE LEGAL FRAMEWORK FOR COAL DEVELOPMENT IN ALBERTA
}

\author{
L. DOUGLAS RAE*
}

This paper examines the legal and regulatory regime that has been developed by the government of the Province of Alberta in order to implement the specific aspects of the Alberta coal policy.

\section{INTRODUCTION}

In June of 1976 the government of the Province of Alberta, through the Department of Energy and Natural Resources, issued a landmark document which was to be the basis for coal development in the province from that time forward. Entitled "A Coal Development Policy for Alberta" it is commonly referred to as the "coal policy". In the five years since the document's issuance, the Alberta government has, for the most part, implemented both the general and specific aspects of the policy. It is the purpose of this paper to outline the legislative and regulatory framework through which the coal policy is currently being implemented.

The coal policy purports to govern the extraction of coal resources by all methods, including surface mining, underground mining and in situ processes yet to be developed. It must be remembered that the coal policy not only governs the exploration for and extraction of coal resources, but also designates those areas which for the foreseeable future are to be untouched by coal development.

Coal deposits in Alberta underlie large areas of the plains, foothills and Rocky Mountains. The coal policy, as it relates to deposits found in the foothills and Rocky Mountains, must be applied in conjunction with the land use zones specified in "A Policy for Resource Management of the Eastern Slopes," which has direct impact on the manner and method of coal development in those areas.

It should be emphasized at the outset that the coal policy in both its theoretical basis and its implementation and administration was not designed to be a legal document, but rather an administrative one. While portions of it have been legislated into existence, many aspects of the coal policy are enforced through administrative dictates rather than through any legal sanctions. In many instances discretion and flexibility take precedence over legal rights.

The procedure for government consideration of applications for new coal developments is a four-step screening and evaluation process ${ }^{3}$ consisting of the following:

1. Preliminary disclosure of a development proposal to the government and the government's initial response thereto. ${ }^{4}$

* Vice President Legal, Asamera Inc., Calgary.

1. Alberta. Department of Energy and Natural Resources, "A Coal Development Policy for Alberta" (15 June 1976).

2. Alberta. "A Policy for Resource Management of the Eastern Slopes" (July 1977).

3. Supra n. 1 at 4.

4. This is strictly an administrative procedure whereby the government through the Cabinet, has undertaken to advise a prospective developer at an early date whether it has any objections to his pursuing plans for the development. There is no legal requirement to make a preliminary disclosure, nor is there any obligation for the government to respond to it. Theoretically, a developer could proceed to apply for a mine permit even though he had been advised that the government would not approve it. 
2. Disclosure and detailed description of the proposal by the applicant to the public. ${ }^{5}$

3. Consideration through a public hearing before the Energy Resources Conservation Board (E.R.C.B.) of the formal aspects of the application, including the basic technical application, the cost-benefit and social impact analysis, the environmental impact assessment and a land surface reclamation plan. ${ }^{6}$

4. A final decision by the Lieutenant Governor in Council in light of the findings of the E.R.C.B. and the various government departments concerned. ${ }^{7}$

It is not the purpose of this paper to conduct a detailed examination of the administrative process required for approval of a coal development project. This matter has been thoroughly covered in the E.R.C.B. publication entitled "How to Apply for Government Approval of Mining Activities in Alberta."

\section{ELEMENTS OF THE COAL POLICY}

The coal policy consists of twenty-four specific elements:

\section{A. Protection of the Environment}

The Government's environmental protection policy for surface and subsurface operations applies equally to public and private land, whether located on the Plains, in the Foothills or in the Mountains.

The Government is committed to maintaining a balance between resource development and environmental protection in order to maintain a desirable quality of life for future Albertans.

Reconnaissance surveys will only be permitted in environmentally sensitive areas under carefully controlled conditions. Detailed exploration and development operations will not be permitted in areas where the environment and plant and wildlife cannot be properly protected and where reclamation of any disturbed land is not possible.

Environmental impact assessments will be required from those proposing major developments and these will be available to public scrutiny and discussion at both specially convened public disclosure meetings and formal public hearings conducted by the Energy Resources Conservation Board. All operations will be subject to the environmental standards and conditions of The Clean Air Act, The Clean Water Act, The Land Surface Conservation and Reclamation Act and The Water Resources Act. A pprovals under environmental legislation will be granted only under conditions where all appropriate measures are taken for the protection of the environment and where environmental standards and criteria are not exceeded. A developer will be expected to absorb all costs attributable to his project of protecting the environment both during and upon completion of operations."

As is the case with most matters concerning the biophysical environment in Alberta, the Department of the Environment has general jurisdiction over the environmental aspects of coal development. However, since the coal policy encourages a "one window" approach to the public hearing process and since this one window is before the

5. The coal policy states that this is "required", but there is no specific legislative authority to order such a public disclosure meeting. The author is not aware of any coal development proposals that have not been preceded by a public disclosure meeting.

6. The actual application for a mine permit is made to the E.R.C.B. pursuant to s. 10(1)(b) of The Coal Conservation Act. S.A. 1973, c.65, as am., and a hearing is held pursuant to s. 29 of The Energy Resources Conservation Act, S.A. 1971, c. 30, as am.. The public hearing is not mandatory.

7. This is only required for mines capable of producing more than 45,000 tonnes of coal per year. The Lieutenant Governor in Council can also attach conditions to his approval. See Coal Conservation Act, id, s. 21.

8. Energy Resources Conservation Board, Guide G-2, "How to Apply for Government Approval of Mining Activities in Alberta" (September 1978).

9. Supra n. 1, s. 3.1. 
E.R.C.B., that Board also has certain jurisdiction to consider matters concerning the environment, if not to rule upon them. ${ }^{10}$ The Board, in effect, is delegated responsibility for devising and administering the ways and means required to ensure that environmental standards are met. The general nature of the respective mandates of the E.R.C.B. and the Department of the Environment has resulted in some dispute and confusion as to the respective jurisdictions of each body. They have consequently attempted to remedy the situation by reaching a ministerial accord whereby jurisdiction is "divvied-up"." In spite of this accord, clearly an interested third party could raise matters of an environmental nature at the E.R.C.B. hearing rather than relying upon the Department of the Environment, since this is the only public scrutiny of these matters and since environmental matters are within the jurisdiction of the E.R.C.B. The E.R.C.B. has oftentimes appointed a senior staff person of the Department of the Environment to sit on specific hearing panels. ${ }^{12}$

Some areas of the province are totally out of bounds to coal development. ${ }^{13}$ The Land Surface Conservation and Reclamation Act gives the Minister of the Environment the power to remove specified areas from exploration potential. ${ }^{14}$ As well, certain areas have already been removed by regulation from exploration potential. ${ }^{15}$

The environment protection portion of the coal policy is applicable to both public and privately owned land and both surface and subsurface disturbances. Since coal mines by their nature involve a disturbance to the land, they fall within the ambit of s. 23 of The Land Surface Conservation and Reclamation $\mathrm{Act}^{18}$ by virtue of $s .3$ of The Regulated Coal Surface

10. The Board is governed by the purposes of The Energy Resources Conservation Act, S.A. 1971, c. 30, as am., s. 2(d): "to control pollution and ensure environment conservation in the exploration for, processing, development and transportation of energy resources and energy"; by the purposes of The Coal Conservation Act, S.A. 1973, c. 65, as am., s. 4(e): "to assist the Government to control pollution and ensure environment conserva. tion in the development of the coal resources of Alberta"; and by The Coal Conservation Regulations, Alta. Reg. 229/74, s. 25: "An operator shall institute and carry out a program of environment management, including pollution control and surface reclamation. satisfactory to the Board."

11. Alberta Environment, "Accord Between Alberta Environment and the ERCB on Procedures for Energy Related Projects that have a Significant Environmental Impact" (May 29, 1980). See also Energy Resources Conservation Board Informational Letter IL 80-19. "Environmental Impact Assessments."

12. See Energy Resources Conservation Board and Alberta Department of Environment, ERCB-AE Report 77-AA, In The Matter Of Applications By Calgary Power Ltd. For The Extension Of The Highvale Mine And The Construction And Operation Of A Proposed South Sundance Thermal Power Plant (A ugust 1977).

13. See section $M$, infra.

14. The Land Surface Conservation and Reclamation Act, S.A. 1973, c. 34, as am., s. 10:

The Minister may by order

(a) establish specified areas within which any type of exploration operations may be prohibited or curtailed, or

(b) establish specified areas within which any type of exploration operations may be prohibited during a specified period of the year.

and see also

Exploration Regulation, Alta. Reg. 423/78, s. 5(1):

No person shall conduct a type of exploration within an area while that method of ex. ploration is prohibited in that area by an order of the Minister of the Environment under section 10 of The Land Surface Conservation and Reclamation Act.

15. Exploration Regulation, Alta. Reg. 423/78, s. 4(1).

16. S.A. 1973 , c. 34 , as am. 
Operations Regulations. ${ }^{17}$ Consequently, a development and reclamation permit must be applied for, pursuant to s. 8 of The Regulated Coal Surface Operations Regulations, ${ }^{18}$ prior to the commencement of any coal development. Procedurally, the development and reclamation permit is applied for at the same time as the actual mine permit is applied for. ${ }^{19}$

Under s. 8 of The Land Surface Conservation and Reclamation Act, the Minister of the Environment may order that an environmental impact assessment be conducted. ${ }^{20}$ This is apparently the only authority for ordering the conduct of such assessments under provincial legislation. ${ }^{21}$ Although the Department of the Environment has issued Environmental Impact Assessment Guidelines, currently under revision, ${ }^{22}$ there is no legislation nor are there regulations governing the contents and the preparation of such assessments. The E.R.C.B. publication, "How to Apply for Government Approval of Mining Activities in Alberta," ${ }^{23}$ sets out the purpose of an environmental impact assessment: "The purpose of an EIA is to provide comprehensive information, to both the public and government, to allow early identification and resolution of potentially significant adverse environmental effects of the proposed development."24 The coal policy states that such assessments will be made available to public scrutiny at the public disclosure meetings contemplated under the policy. However, not only is such public scrutiny of the impact assessments at these meetings not legislated, the holding of such disclosure meetings itself is not legislated. In practice environmental impact assessments have not always been available at these public disclosure meetings. ${ }^{25}$ There have even been instances where the final form of environment impact assessment has not been available at the formal E.R.C.B. hearing. ${ }^{26}$

Coal mining operations in Alberta are subject to the pollution standards and emission limits established pursuant to The Clean Air Act and The Clean Water Act. ${ }^{27}$ As well, the use of ground water and surface water resources is governed by The Water Resources Act and, when water is required in sufficient quantities, permits under that Act must be acquired. ${ }^{28}$ It should be pointed out that The Clean Air Act and The Clean Water Act primarily provide for limitations of point specific effluent emissions. They do not expressly provide for "all appropriate measures"

17. Alta. Reg. 170/74.

18. Id.

19. Supra n. 8.

20. Supra n. 13.

21. Land Conservation Regulations, Alta. Reg. 125/74, s. 12.

22. Alberta Environment, "Review of Alberta's Environmental Impact Assessment System, Report and Recommendations" (June 1980).

23. Supra n. 8 at 5-18.

24. See also Alberta Environment. "Environmental Impact Statement Guidelines for Clean Air Act Application," (16 May 1974) Foreward:

It is intended that these guidelines should delineate and emphasize the various aspects of environmental management which should be considered in the planning stage in order that plant design will ensure the preservation of the ecologic integrity of the area of impact.

25. E.g. the Obed Marsh Project public disclosure meeting.

26. E.g. Esso Resources Cold Lake Project.

27. The Clean Air Act, S.A. 1971, c. 16, as am.; The Clean Water Act, S.A. 1971, c. 17, as am..

28. R.S.A. 1970 , c. 388 , as am.. 
required for the protection of the environment, although there is a general ministerial discretionary authority under other legislation. ${ }^{29}$

The Clean Air Act requires a permit for construction of any coal processing plant. ${ }^{30}$ Although processing plants must comply with the emission standards set by regulation, the Director of Standards and Approvals also has wide latitude to attach additional terms and conditions. ${ }^{31}$ Subsequent to construction, a licence to operate is also required ${ }^{32}$ and once again the Director of Standards and Approvals has wide discretion to impose terms and conditions. ${ }^{33}$ The Minister of the Environment has the power to "issue a certificate of variance to vary a term, condition or requirement of a permit or licence or a requirement of the regulations". ${ }^{34}$ The Director of Pollution Control also has the power to issue "emission control orders" where emission standards are being exceeded or where an air contaminant is likely to be detrimental to life or health or to adversely affect property.$^{35}$ An emission control order can be issued notwithstanding that a plant is operating pursuant to an operating licence. ${ }^{36}$ Finally, the Minister of the Environment has wide discretion to issue a "stop order" pursuant to s. 7 of the Act. If the Act, Regulations, orders or directions of the Director of Pollution Control or a term or condition of a licence are being contravened, or if there is an immediate danger to human life or property, the Minister may shut down the operation of the plant. The issuance of stop orders is one area where elaborate appeal procedures have been set out in the legislation. In addition, practice has shown that the Minister of the Environment issues stop orders only as a last resort..$^{37}$

29. E.g. the ability to attach conditions to a coal plant approval or to a development and reclamation approval.

30. S.A. 1971, c. 16, as am., s. 4.

31. Id., s. $4(5)$.

32. Id., s. 4.1.

33. Id. s. 4.1(6).

34. Id. s. 4.8(1):

The Minister may issue a certificate of variance if he is of the opinion that

(a) the plant, structure or thing is operating or is likely to operate in contravention of a term, condition or requirement of a permit or licence or a requirement of the regulations as a result of factors beyond the control of the applicant.

(b) the variation is not likely to result in air pollution of a degree that could be detrimental to life or health or adversely affect property, and

(c) a refusal to grant a certificate of variance would result in serious hardship to the applicant without an offsetting benefit to others.

35. Id., s. 6.

36. Id., s. 6(5).

37. It does not appear that a stop order has ever been issued for a coal processing plant operation. The Department of the Environment has implied that it will only issue a stop order when "the frequency of violations" is deemed excessive. (See supra n. 12 at 12.9) See also s. 9, Land Surface Conservation and Reclamation Act, supra n. 17, which provides for the issuance of a stop order where there are reasonably unforeseen "surface disturbance or other damage or consequences". However, it does not appear that a stop order can be issued for a violation of conditions imposed pursuant to ss. 21 or 24 of The Coal Conservation Act, supra n. 6. In other words, the Minister of the Environment may impose conditions but may not have the power to issue a stop order pursuant to $\mathrm{s} .9$ of The Land Surface Conservation and Reclamation Act if they are breached. In view of the wide latitude to direct reclamation procedures under Part 2 of The Land Surface Conservation and Reclamation Act, however, this inability to issue stop orders may not prove to be a serious impediment to ministerial discretion. 
The Department of the Environment has authority to prepare and publish guidelines and standards for the construction and operation of coal processing plants. ${ }^{38}$ It is not clear what status such guidelines and standards would have. It is also not clear whether a construction permit issued pursuant to s. 4 of the Act is the permission of the Director of Standards and Approvals required for the release of toxic air contaminants into the atmosphere.$^{39}$ Section 12 of The Clean Air (General) Regulations requires the reporting of uncontrolled or unauthorized releases of air contaminants. The Clean Air Regulations set forth the requirements for construction permits and operating licences necessary for compliance with the Act.

A permit under The Clean Water Act must be obtained by a coal processing plant..$^{40}$ As under The Clean Air Act, the Director of Standards and Approvals has wide latitude under The Clean Water Act. ${ }^{41}$ Likewise, an operating licence is required and the Director of Standards and Approvals has broad discretionary powers. ${ }^{42}$ "Certificates of variance", "water quality control orders" and "stop orders" are also provided for. ${ }^{43}$ Section 9.1 prohibits the deposit of a deleterious substance in surface water, on a watercourse, or in any place where it may enter a watercourse or surface water. However, this section does not apply to an approval, permit or licence issued by the E.R.C.B.. ${ }^{4}$ Presumably, E.R.C.B. approvals for the mine and processing plant would therefore take a coal mine and processing plant outside the ambit of this section. ${ }^{45}$ Section 12 of The Exploration Regulation ${ }^{46}$ issued under The Mines and Minerals Act ${ }^{47}$ also provides for a referral to the Department of the Environment if an exploration program involves a watercourse or water body.

The Department of the Environment has also issued the "Alberta Coal Mining Waste Water Effluent Guidelines." 48 They are to apply to all new coal mines. "Permits to construct or licences to operate under The Clean Water Act will be issued provided that the provisions of these guidelines have been considered and adequate waste water management provided to comply with the standards." ${ }^{49}$ The guidelines are quite comprehensive and come complete with definitions. If clean water permits and licences are subject to these guidelines, one wonders why they have not been promulgated in regulation or legislative form. Presumably the guidelines

38. Clean Air (General) Regulations, Alta. Reg. 216/75, s. 4.

39. Clean Air Regulations, Alta. Reg. 33/73, s. 5.

40. Clean Water Act, S.A. 1971, c. 17, as am., s. 4.

41. Id., s. 4(5).

42. Id. ss. 4.1 and 4.4 .

43. Id. ss. $4.9,6$ and 7 .

44. Id. s. 9.1 .

45. See, however, Clean Water (General) Regulations, Alta. Reg. 35/73, s. 11.

46. Supra n. 18.

47. R.S.A. 1970 , c. 238 , as am..

48. Alberta Environment. "Alberta Coal Mining Waste Water Effluent Guidelines" (January, 1978).

49. Id. Preface. 
have been issued pursuant to s. 6 of The Clean Water (General) Regulations. ${ }^{\text {so }}$

In addition, ss. 30 and 31 of The Coal Conservation Regulations $\mathrm{s}^{51} \mathrm{em}$ power the E.R.C.B. to direct the method of disposal of liquid and solid wastes. Should a conflict arise between an order of the Board in regard to waste disposal and a direction of the Department of the Environment, the E.R.C.B.'s statements and policies suggest that the Board would defer to the Department of the Environment. ${ }^{2}$ It must be kept in mind that both the E.R.C.B. and the Department of the Environment can attach environmental conditions to a mine permit or a processing plant approval issued under The Coal Conservation Act. ${ }^{53}$ The E.R.C.B. also has power to require security deposits in amounts up to $\$ 1,000$ per acre directly affected by the proposed development. ${ }^{54}$ These deposits can be utilized to ensure environmental protection.

Under the Historical Resources Act, the Minister of Culture may order proponents of a coal development to prepare historical resources impact assessments and to undertake directed conservation measures prior to development. ${ }^{55}$ The E.R.C.B. Mining Guide, "How to Apply for Government Approval of Mining Activities in Alberta", sets out the purpose for the legislation and the contents that Alberta Culture feels should be in any historical resources impact assessment. ${ }^{56}$

50. Supra n. 45:

The preparation, publication and sale of such criteria and guidelines with respect to the construction or operation of any water facility as the Minister thinks fit is authorized.

51. Alta. Reg. 229/74.

52. Supra n. 8. See also the Board's deferral to the Department of the Environment in regard to the siting of ancillary facilities.le.g. Energy Resources Conservation Board and Alberta Department of Environment, ERCB-AE Report 79-AA, In The Matter Of Applications By Alberta Power Limited, Forestburg Collieries Limited And Manalta Coal Ltd. For The Development Of The Sheerness Mine And The Construction And Operation Of A Proposed Sheerness Thermal Power Plant and In The Matter Of Applications By Edmonton Power For The Development Of The Genessee Mine And The Construction And Operation Of A Proposed Genessee Thermal Power Plant (January 1979), s. 9.2. The Board in its findings will state how a particular concern can be alleviated, but does not always then attach an appropriate condition to the permit or approval. This may reflect a lack of confidence by the Board as to the extent of its jurisdiction.

53. S.A. 1973, c. 65 , as am., ss. 23 and 24.

54. See Energy Resources Conservation Board Report No. 80.E, Obed Marsh Coal Projech. Hinton (July 1980).

55. The Alberta Historical Resources Act, S.A. 1973, c. 5, as am., s. 22.

56. Supra n. 8, at 5-22:

The intention is to stimulate conservation projects designed to locate, assess, recover, and record Alberta's historical, archeological, and paleontological resources.

It is not the wish of the Heritage Resources Division of Alberta Culture to impede or halt any industrial development or other project, in pursuit of such conservation, although the Minister is empowered to do so should a valuable resource be threatened with destruction.

In every instance, Culture wishes to encourage all proponents to ensure that their activities will not result in the destruction of valuable historic, archeological, or paleontological sites before these can be properly assessed and recorded.

Supra n. 8, at 7-6:

The ERCB, and Alberta Culture through the Archeological Survey of Alberta, assume certain responsibilities in preserving significant archeological, historical, and paleontological resources that may otherwise be disturbed or destroyed by energy. related developments within the ERCB's jurisdiction..... 
In addition, the Department of Culture has issued "Interim Guidelines, Historical Resources Impact Assessments". ${ }^{57}$ The legal status of these guidelines is unclear. The E.R.C.B. has also issued interim directives entitled, "Preservation of Archaeological, Paleontological and Historical Resources", ${ }^{88}$ and has stated that it will require such surveys for all coal mine permit applications. After the proponent has advised the Director of the Archaeological Survey of Alberta of its assessment, the Director apparently will recommend the steps the proponent should take to ensure preservation and will entertain discussions with the proponent should the latter "consider the Director's recommendations impractical" ${ }^{59}$ Only those site preservation measures that are agreed upon will definitely be included as conditions in any permit, licence or approval the E.R.C.B. may subsequently issue. ${ }^{60}$ If, when proceeding with an authorized development, a previously unsuspected archaeological, historical or paleontological resource is encountered, the E.R.C.B. has stated that its staff should be notified, although there does not appear to be any obligation to do so. After examination of the site by the Director of the Archaeological Survey of Alberta, and where necessary, "the ERCB will then formally ensure compliance with the agreed upon measures by issuing a directive" to the proponent or by amending the subsisting permit, licence or approval. ${ }^{61}$

\section{B. Compatibility with other land uses}

The Government recognizes the importance of Alberta's land resources for agriculture, recreation, forest products and wildlife, and is determined that proper attention be given to these alternative uses in the consideration of coal development projects. Some coal developments may be carried on with little disturbance of the land surface; others may involve the progressive disturbance of several square miles at any one time with reclamaton immediately to follow production operations. Only where the temporary withdrawal of the land from agricultural, recreational or other use for coal development is judged to be in the public interest, and where full reclamation is assured, will the Government authorize developments which would cause land disturbance. ${ }^{62}$

A basic premise behind both the Eastern Slopes policy ${ }^{63}$ and the coal policy is the multiple use concept. In order for this concept to operate, only where the withdrawal of land from other uses for coal development is judged to be in the public interest and where full reclamation is assured, will the government authorize coal development which would cause land disturbance. Since permission to allow development of a major coal mine is subject to the approval of the Lieutenant Governor in Council, ${ }^{64}$ he is the ultimate judge of the public interest in this regard. ${ }^{65}$ Since surface coal mining in Alberta on a large scale is still in its infancy, what constitutes "full reclamation" is yet to be defined or evidenced by empirical data. The Department of the Environment, in its approval of reclamation plans to date, appears willing to accept scientific probabilities of full reclamation

57. The Archaeological Survey of Alberta. "Interim Guidelines Historical Resources Impact Assessments" (March 15, 1977).

58. E.R.C.B. Interim Directives 77.1 and 79.18.

59. Supra n. 8 at 7-6.

60. Supra n. 8 at $7 \cdot 6$.

61. Supra n. 8 at $7-7$.

62. Supra n. 1, s. 3.2

63. Supra n. 2.

64. Supra n. 53, s. 21.

65. However, the E.R.C.B. will make recommendations designed to minimize surface disburbance, supra n. 12 at 11-18. 
rather than any "assured" full reclamation. ${ }^{68}$ However, with the predicted widespread development of surface coal mining operations in areas of prime agricultural land, the issue of full reclamation will certainly have to be addressed further. Totally successful reclamation techniques in certain agricultural areas have yet to be established. ${ }^{67}$

Where existing or future land uses require ground water supplies, there does not appear to be any legal or technological guarantee of reinstatement of the underground aquifers. Nor does there appear to be provision for compensation for loss of ground water, although presumably the loss of ground water supplies would be reflected by a reduction in the market value of the land taken. However, if the land is not actually taken for the mine and ground water supplies are interrupted, there is no right to compensation. ${ }^{68}$

\section{Rights of owners of surface land}

The rights of the owners of surface land are recognized and will be respected along with those of owners or lessees of coal resources. Holders of rights to coal who do not own the surface will be expected to negotiate with the owners and occupants of the surface for consent to enter and for the temporary use of the land. Should negotiations fail, application may be made under the Surface Rights Act to the Surface Rights Board. The Board would hold a hearing on the application at which representations from the surface owner, lessee or occupant and any other interested party would be received. Where the Board grants a right of entry order it also determines what compensation should be paid and to whom. In determining the compensation the Board may consider a variety of matters, including the value of the land, the loss of use by the owner or occupant, adverse effects on the owner or occupant and damage to the land. ${ }^{\circ 9}$

The coal policy does not purport to alter the rights and procedures affecting private surface rights owners and occupants from that which already exists in regard to oil and gas well and pipeline operations. Holders of rights to coal are not only expected, but are obligated to negotiate with the owners and occupants of the surface if right of entry is desired. ${ }^{70}$ If negotiations fail, right of entry can be obtained pursuant to the Surface Rights Act. ${ }^{11}$ Where application is made to the Surface Rights Board for right of entry, a hearing before the Board is mandatory. ${ }^{72} \mathrm{Com}$ pensation is determined pursuant to 5.23 of the Act. ${ }^{.3}$ The Board also has the right to arbitrate disputes between a mineral right owner and the owner or occupant of the surface for damage claims in amounts up to $\$ 2,000$. $^{74}$ The Land Surface Conservation and Reclamation Council also

66. Supra n. 54 at 42 , "satisfactory reclamation would be possible".

67. E.g. in soils containing large amounts of sodium and smectite clays (bentonite). Doubts have also been raised about reclamation in forested areas as well. See St. Regis (Alberta) Ltd. intervention in Obed Marsh hearing, supra n. 54 at 42.

68. Supra n. 12.

69. Supra n. 1, s. 3.3.

70. W.N. Richards and F.C.R. Price, "Surface Rights Acquisition and Compensation" (1982) 20 Alta L. Rev. at supra p. 1.

71. S.A. 1972 c. 91 , as am., ss. $12(3)$ and $15(1)$.

72. Id. at supra p. 1., s. 17 .

73. Although the E.R.C.B. has no jurisdiction over compensation, it does on occasion make its views known in this regard, supra n. 58 at 9-12.

74. Id, s. 38. It appears that the E.R.C.B. does not feel that a county is entitled to compensation for or replacement of its roads that are lost to coal development, see Energy Resources Conservation Board and Alberta Department of Environment, ERCB-AE Report 78-AA, In The Matter Of An A pplication By Forestburg Collieries Limited For A Permit To Develop And A Licence To Commence Mining Operations At A Mine Site near Halkirk (June 1978) at 6-7. 
has the power, with the consent of the parties concerned, to arbitrate damage claims. ${ }^{75}$

Recently conflicts have arisen between the owners of different subsurface rights. ${ }^{78}$ Surface coal mines and oil and gas drilling cannot take place at the same time in the same area. ${ }^{77}$ Notwithstanding ss. 25 and 26 of The Mines and Minerals Act, which state that a person who has the right to work a mineral may work through any other mineral in the same tract to the extent necessary to obtain his mineral without permission from or compensation to any other person, ${ }^{78}$ it may be that at some point the Surface Rights Act will have to be utilized to compensate a mineral right owner who has suffered loss due to the actions of another mineral right owner. To date there have been no such claims for compensation and conflicts have either been resolved between the parties themselves or by the E.R.C.B. ${ }^{79}$ Presently the Department of Energy and Natural Resources, in advertising sales notices of Crown petroleum and natural gas rights, identifies those lands subject to a mine permit issued by the E.R.C.B. ${ }^{80}$ The E.R.C.B. also has new guidelines setting forth how these types of conflicts should be resolved. ${ }^{81}$ These guidelines basically provide that well licences will not be granted in areas that are subject to a ten year mine plan in an approved mine site. The Department has stated that in appropriate circumstances oil and gas lease extensions pursuant to s. 12.1(1)f of The Mines and Minerals Act would be granted.

\section{Land surface reclamation}

The primary objective in land reclamation is to ensure that the mined or disturbed land will be returned to a state which will support plant and animal life or be otherwise productive or useful to man at least to the degree it was before it was disturbed. In many instances the land can be reclaimed to make it more productive, useful, or desirable than it was in its original state; every effort will be made towards this end.

The Land Surface Conservation and Reclamation Act requires the filing of an Environmental Impact Assessment as well as acceptable detailed mining and reclamation plans before approval to proceed with mining is granted. In addition, a security deposit based on the degree of disturbance and the quantity of coal produced will be required to ensure complete and satisfactory compliance with the regulations and approvals.

Land reclamation will include the contouring of the mined or disturbed lands, the replacement of the top soil, revegetation for soil stabilization, biological productivity and appearance, and suitable maintenance of the vegetation or, where appropriate, the conversion of the land to agricultural or other desirable use. Where applicable it will also include the replacement or rehabilitation of those facilities or features which were disrupted during the mining process and which are required to return the land to its former use. Since each reclamation program will be especially designed to suit the projected future use of the land, it will be necessary to establish this future use early in the review process. Representations will be invited from interested persons. especially any affected landowners and municipal governments.

75. The Land Surface Conservation and Reclamation Act, S.A. 1973, c. 34, as am., s. 61.

76. See Energy Resources Conservation Board Decision Report 80-24, Chinook Management Ltd. Licence to Drill a Well

77. Although there are procedures to allow surface mining over an oil or gas well, see Report of Canadian Petroleum Association Committee on Problems Associated with Mining and Petroleum Operations within the same Geographic Area (12 February 1980).

78. Supra n. 47.

79. Supra n. 76. See also supra n. 52 at 11-4.

80. E.R.C.B. Informational Letter 80-11, "Identification of Coal Permit Areas in Sales Notices of Crown Petroleum and Natural Gas Rights."

81. E.R.C.B. Informational Letter 80-14, "Coal Mining and Well Drilling in the same Land New Policy." 
The Government will accelerate its current reclamation program on lands which were mined prior to effective reclamation legislation in 1973 with the objective of rendering the lands suitable for further beneficial uses. It will expect the coal industry to assist in this program. ${ }^{\text {az }}$

The purpose of the Alberta reclamation policy is not to restore the land to exactly the same contours, productivity, and so on that existed prior to the land being disturbed. Pursuant to s. 23 of The Land Surface Conservation and Reclamation Act, s. 3 of The Regulated Coal Surface Operations Regulations and The Land Conservation Regulations, ${ }^{83}$ the opening up, operation, alteration, extension, or abandonment of a mine is designated a regulated surface operation. Approval to commence operations is required pursuant to s. 24 of the Act. ${ }^{84}$ The Minister of the Environment has final approving authority over any such operation and may impose conditions as he sees fit. ${ }^{85}$ This approval is presumably the development and reclamation approval that is provided for under The Regulated Coal Surface Operations Regulations. ${ }^{86}$

Applications for a development and reclamation approval go to the Development and Reclamation Review Committee established under Part 4 of The Land Conservation Regulations ${ }^{87}$ to determine compliance with the regulations. This committee is composed of representatives from interested government departments. It examines "the general and overall impact of the proposed operation on the environment in relation to the Land Conservation Guidelines and the Development and Reclamation Guidelines ...., the ability of the applicant to complete in a satisfactory manner, the proposed operation and any reclamation required in connection therewith, and the past performance of the applicant in respect of any prior operations or reclamation conducted by him" ${ }^{88}$ The committee does have the power to recommend changes in the regulations or guidelines. ${ }^{89}$ The committee also has authority to recommend a public meeting be held in regard to the application. ${ }^{90}$ The Minister of the Environment or the

82. Supra n. 1, s. 3.4.

83. Supra n. 75, supra n. 17 and supra n. 21 respectively.

84. Supra n. 75 s. 24:

Unless he has first obtained an approval therefor under this Part, no person shall, subject to subsection (3), commence or continue or recommence any operation or activity in, upon, or over the surface of any land where

(a) the operation or activity is of a kind designated by the regulations under section 23 as a regulated surface operation, and

(b) the land to be affected by the operation or activity is within a part of Alberta to which the designation applies.

85. Supra n. 75, s. 27:

(1) Subject to any regulations under section 25, subsection (1), clause (d), the Minister may grant or refuse to grant the approval or may require a change in the specifica. tions or location as a condition precedent to granting an approval.

(2) The Minister may

(b) make an approval subject to conditions, or

(c) specify requirements as to the manner in which land conservation and reclamation is to be conducted.

86. Supra n. 17, s. 8.

87. Supra n. 21.

88. Id, s. 22(1).

89. Id, s. 14. In the case of the expansion of the No. 9 Mine Site near Grande Cache, the committee prepared specific guidelines for the proposed expansion, see Energy Resources Conservation Board and Alberta Department of Environment, ERCB-AE Report 77-BB, In The Matter Of An Application By McIntyre Mines Limited For The Extension Of The No. 9 Mine Site Near Grande Cache (November 1977) A ppendix 3.

90. Supra n. 22, s. 14(3). 
Chairman of the Land Conservation and Reclamation Council receives the recommendations of the Development and Reclamation Review Committee and either grants or refuses the development and reclamation approval. ${ }^{91}$ Where "an operation will result in substantial permanent damage of sufficient magnitude to the environment" the Minister of the Environment may refuse the application or direct the operator to "undertake additional reclamation work to compensate for the loss of resources, especially recreation facilities and, if applicable, ungulate winter rangeland", or provide additional funding to the government for compensatory or amelioratory action. ${ }^{92}$ Recreation facilities and ungulate winter rangeland have special importance attached to them through this regulation..$^{93}$

A development and reclamation plan is mandatory ${ }^{94}$ in order to obtain a development and reclamation approval and the required contents thereof are set forth in Part 5 of The Land Conservation Regulations ${ }^{95}$ and Parts 3 and 4 of The Regulated Coal Surface Operations Regulations. ${ }^{96} \mathrm{~A}$ development and reclamation plan would normally include reports on surface disturbance, geotechnical engineering, surface water management, groundwater management, water and air quality management and pollution control. Notwithstanding that the contents of all these reports are specifically set out in The Land Conservation Regulations, ${ }^{97}$ an applicant may consult with the Department of the Environment in regard to what information or which reports, documents, maps and plans are necessary. The Chairman of the Land Conservation and Reclamation Council may then waive any of these requirements. ${ }^{98}$ Since reclamation as a science is

91. Supra n. 86, ss. 11 and 12.

92. Supra n. 21, s. 23. This assumes that s. 23 of the Land Conservation Regulations applies to a coal mine, however a coal mine may not be an "operation" within the ambit of this section. Generally, The Regulated Coal Surface Operations Regulations rather than the Land Conservation Regulations govern coal mines.

93. For a discussion on ungulate winter rangeland see supra n. 89 at 7-5.

94. Supra n. 17, s. 8 .

95. Supra n. 21, s. 25:

A development report shall consist of an outline of an investigation into the impact of the proposed plan on alternate uses of land in the same location or in close proximity thereto, and shall normally include a discussion, as far as may be applicable, respecting

(a) residential development;

(b) aesthetic and scenic considerations;

(c) active or passive outdoor recreation areas;

(d) environmental considerations of indigenous flora and especially fauna:

(e) existing agricultural, commercial and industrial developments;

(f) proposed transmission and transportation facilities and the need for relocation of existing transmission or transportation facilities;

(g) housing requirements, if any, and related services, including
(i) sewer,
(ii) domestic water,
(iii) electricity,
(iv) telephone,
(v) access roads,
(vi) schools, and
(vii) hospitals.

(h) such other details as may be required to provide an assessment depending on the nature of the site to be developed.

96. Supra n. 17.

97. Supra n. 21.

98. Supra n. 86, s. 9. 
relatively new in Alberta, the degree and methods of reclamation the Council requires are continually being modified.

The specifics of a land reclamation plan can also be gleaned from an analysis of the land reclamation "guidelines". The Development and Reclamation Review Committee has prepared a document entitled "Application Requirements for a Development and Reclamation Approval". In addition, the Land Conservation and Reclamation Council has prepared "Guidelines for the Reclamation of Land Affected by Surface Disturbance". ${ }^{100}$ In these latter guidelines it is reiterated that s. 35 of The Land Surface Conservation and Reclamation Act provides for the making of regulations, but in the absence of regulations s. 36 allows the Council to use other standards. It is the Council's "opinion that regulations at this point in time [presumably December 1977] would be too inflexible for satisfactory application and that more flexible guidelines would be more applicable". ${ }^{101}$ These guidelines are to take the place of the regulations contemplated under s. 35. Reclamation criteria are set out in relative specificity. Although they are stated not to be regulations but only guidelines, the Council clarifies its position stating that the criteria "will be applied by the approving authorities under the Act and regulations". ${ }^{102}$ The guidelines have as a reclamation goal "the return to, or the continuation or resumption of some appropriate land use upon the conclusion of the surface disturbance". ${ }^{103}$ "Some appropriate land use" is presumably the "full reclamation" assured under the coal policy. An operator remains responsible for disturbed land until some indication is given that the reclamation desired is being effected; for example, productivity for agricultural land existing prior to the surface disturbance has been restored.

Although these guidelines do not have the status of legislation, it appears that they are being used as determinative of land reclamation plans. Since they are guidelines, they can be waived or varied at the discretion of the Land Conservation and Reclamation Council. It should be noted that the Council is not one body, but rather consists of different personnel depending on where the disturbance is located. ${ }^{104} \mathrm{It}$ is not known at this time whether the government intends to put into regulation form any of these guidelines.

Presumably the "facilities or features" the coal policy requires be replaced or rehabilitated would include man-made structures and buildings. The construction of buildings on reclaimed land, however, may prove to be a problem. ${ }^{105}$ The future use of the land after reclamation must be established prior to any approval for disturbance being given. The degree to which uses other than the original land use will be permitted remains to be seen and will evolve through practice.

99. The Development and Reclamation Review Committee, "Application Requirements for a Development and Reclamation Approval" (1978).

100. Land Conservation and Reclamation Council, Alberta Environment and Alberta Energy and Natural Resources, "Guidelines for the Reclamation of Land Affected by a Surface Disturbance" (December 1977).

101. Id., at 1 .

102. Id, at 2.

103. Id, at 1.

104. Supra n. 75, s. 15.

105. Supra n. 52 at 20.21 . 
The specifics of the promised public representation include actual participation on the Development and Reclamation Council by local landowners and representatives of the municipal government in the case of lands located within the jurisdiction of a municipal government. ${ }^{108}$

If a party is not satisfied with the terms of his development and reclamation approval he may appeal it to the Minister of the Environment. ${ }^{107}$ As well, the Development and Reclamation Review Committee is obligated to give reasons for any recommendation it makes. ${ }^{108}$ This may enhance the exposure of such decisions to possible judicial review.

Section 12 of The Coal Conservation Act requires that a proposed scheme for reclamation be included in any mine permit application.$^{109}$ In practice, this is the same development and reclamation plan submitted to obtain development and reclamation approval. A mineral surface lease application must also provide for restoration. ${ }^{110}$ At that stage of mine development, however, it is more likely that an applicant would already have his development and reclamation approval, thus fulfilling this requirement.

The Land Surface Conservation and Reclamation Act provides that surface rights in land cannot be surrendered until a reclamation certificate is issued by the Land Conservation and Reclamation Council." ${ }^{11}$ The issuance or non-issuance of reclamation certificates can be appealed, including to the Court of Queen's Bench of Alberta, which hears the matter as a trial de novo. ${ }^{112}$ Where reclamation has not been carried out satisfactorily, the Council may issue a reclamation order ${ }^{113}$ directing proper reclamation, even if the owner or occupant of the surface of the land consents to the release of the operator. ${ }^{114}$ The conditions under which the Council may issue a reclamation order are set out in $\mathrm{s.} 39$ of the Act. ${ }^{115}$ Interestingly, reclamation must be in accordance with the regulations that prescribe criteria or standards, but no reference is made to the use of guidelines in this regard.

106. Supra n. 75, s. 15.

107. Supra n. 21, Part 6.

108. Supra n. 21, s. 13(2).

109. Supra n. 6.

110. The Mineral Surface Lease Regulations, Alta. Reg. 228/58, s. 24.

111. Supra n. 75, s. 49.

112. Supra n. 75, ss. 56 and 57.

113. Supra n. 75, s. 53.

114. Supra n. 75, s. 52.

115. Supra n. 75, s. 39:

(1) Where the Council is authorized to make a reclamation order under this Part, the order may direct the performance of any work that is necessary in the opinion of the Council to do any or all of the following in respect of the land that is the subject of the inquiry by the Council:

(a) subject to subsection (3), to condition, maintain or reclaim the land or any part thereof, and land adjacent thereof, or

(b) to destroy or prevent the growth of noxious weeds or weed seeds, or

(c) to remove or remedy any hazard to human life, domestic livestock or wildlife, or to the conduct of agricultural or other operations, or

(d) to install or repair any fence, gate, cattle guard, culvert or other thing.

(2) A reclamation order shall specify the date by which the work is to be completed.

(3) Where the regulations prescribe criteria or standards for, or the manner of carrying out, the conditioning, maintenance or reclamation of the land, the reclamation order shall be in accordance with the regulations.

(4) A reclamation order shall be directed to the operator concerned. 
A mineral surface lessee is required, prior to surrender of his lease, to "restore the leased area as nearly as possible to the same condition it was in at the time the application for the original lease was made, and such restoration shall be made to the satisfaction of the Minister". ${ }^{116}$ In addition, the Minister of Energy and Natural Resources has the power to direct restoration. It would seem that it is the present intention of the government to have reclamation matters handled by the Department of the Environment, rather than the Department of Energy and Natural Resources and consequently this section may have fallen into disuse. The latter department does, however, play an active role in experimental reclamation test plots.

Part 7 of The Land Conservation Regulations provides for security deposits to ensure reclamation. ${ }^{17}$ Where reclamation has been completed to the satisfaction of the land use officer the deposit is returned pursuant to $\mathrm{s.} 30$ of the Act; ${ }^{118}$ if the land has not been reclaimed all or part of the deposit may be retained. E.R.C.B. approval must be obtained before operations are suspended at a mine and part of this approval requires information as to the status of reclamation. ${ }^{119}$ Annual status reports on reclamation must be given to the Land Conservation and Reclamation Council. ${ }^{120}$

In addition to the requirements for new mines the government has stated that it "will accelerate its current reclamation program on lands which were mined prior to effective reclamation legislation in $1973 "{ }^{121}$ Under the Land Surface Conservation and Reclamation Act, provision is made for the reclaiming of lands to which the new legislation does not apply and that remain in need of reclamation. ${ }^{122}$ Although the coal policy states that the coal industry is expected to assist in this program and although the legislation provides for this, to date such assistance has been merely voluntary on the coal industry's part, as the actual reclamation is being done at public expense and by public authorities. ${ }^{123}$

\section{E. Use of Alberta manpower, services, materials and equipment}

As a matter of policy the Government requires the maximum practical development and use of Alberta manpower, services, materials and equipment in all aspects of resource development, from initial planning and design through construction to final operation. Companies planning new coal developments must demonstrate that all efforts have been made to comply with the Government's policy in this regard.

This means, for example, that Alberta-based engineering and construction firms are to be given every opportunity to participate in the planning and conduct or operation of coal exploration and development projects, in the design and construction of equipment and plants, and in the related environmental protection and reclamation programs. Where local expertise is lacking or is only partly developed, developers will be expected to work with trade and professional associations and the Government to ensure that Albertans are given the opportunity to acquire the necessary skills and build their capability for future needs.

116. Supra n. 110, s. 24(1)(b).

117. Supra n.21.

118. Supra n. 16.

119. The Coal Conservation Regulations, Alta. Reg. 229/74, s. 12.

120. Supra n. 17, s. 16.

121. Supra n. 1.

122. Supra n. 75, ss. 44 and 45.

123. Although apparently in the Crowsnest Pass area the government has used reclamation deposits for existing leases to reclaim old mine sites. 
The same principle applies to the provision of services, materials and equipment, including the design, construction and operation of facilities for manufacturing or fabricating essential materials and equipment in Alberta. ${ }^{24}$

The government has placed a major emphasis on this aspect of the coal policy. The prime method of ensuring compliance is through the Lieutenant Governor in Council's required approval for all coal mining operations over 45,000 tonnes per year and its ability to attach conditions thereto. ${ }^{125}$ In addition, in deciding on the granting of any mine permit, the E.R.C.B. clearly wishes the applicant to make its plans in this regard known to it. ${ }^{128}$ An examination of applications before the E.R.C.B. reveals examples of undertakings applicants are prepared to give in this regard. ${ }^{127}$ The E.R.C.B. can then use its general jurisdiction to recommend approval conditions designed to implement this purpose of the coal policy. ${ }^{2}$

Unlike some other jurisdictions, ${ }^{129}$ Alberta grants no express competitive advantage to Alberta companies. What constitutes "the max-

124. Supra n. 1, s. 3.5.

125. See supra n. 7, approval of the Obed Marsh Project, which was made subject to the following condition:

The government has formalized a reporting procedure which can be negotiated and modified on a project by project basis as mutually agreed between the project owners/sponsors and the Department of Economic Development. A project owner/sponsor is required to notify the Department of the estimated Alberta, Canadian and foreign content for engineering, project management, and the overall project capital expenditure, the bidders' lists for engineering contractors, the project's organization chart, a list of business opportunities relating to the project, the project's procurement office in Alberta, monthly procurement reports listing significant purchase orders and subcontracts, monthly commitment reports showing cumulative estimates of Alberta, other Canadian and foreign content, and various other information. The government maintains the confidentiality of such information, but demands full access to procurement information by industry development senior officers in order to satisfy the government that fair opportunity was provided to supply engineering, manufacturing and construction goods and services to the project.

See Alberta Economic Development, Policy to Maximize Alberta and Canadian Content:

In developing this program of support, it is realized that local firms must always be competitive in quality, price, delivery time, and post-installation services and it should be clearly understood that the policy is not intended to become a penalty to projects or a bonus for local suppliers.

Providing the foregoing conditions are met, it would be expected that the contracts and purchase orders on projects would be awarded to those firms which provided the greatest Alberta content in their bids and engineering proposals.

126. See Obed Marsh Project. Application No. 790729, Request for Additional Information Cost/Benefit and Social Impact Analysis Obed Marsh Thermal Coal Project (12 November, 1979).

127. See Obed Marsh Project. Application No. 790729, and Esso Cold Lake Project, Application No. 770866.

128. Supra n. 53, s. 7:

The Board, with the approval of the Lieutenant Governor in Council, may make such just and reasonable orders or directions as may be necessary to effect the purposes of this Act but are not otherwise specifically authorized by this Act.

Supra n. 53, s. 14(c):

Upon receiving an application under section 10,11 , or 13 , the Board may, after considering the circumstances of the particular case,... grant a permit or licence or an amendment of a permit or licence, as the case may be, subject to such conditions, restrictions or stipulations as it may consider appropriate and set out in the permit or licence or amendment.

However, the Supreme Court of Canada has ruled that the E.R.C.B.'s authority to attach conditions is not unlimited. See A thabasca Tribal Council v. Amoco Canada Petroleum Company $L$ td. et al unreported, (22 June 1981), 58-03; 3242-01 (S.C.C.)

129. E.g. Bill C-48, the proposed Canada Oil and Gas Act. 
imum practical development and use" is at the discretion of the Lieutenant Governor in Council.

\section{F. Townsites and infrastructure}

The Government is aware of the critical importance to any expansion of the coal industry of the availability of townsites, residences and commercial activities as well as schools, hospitals and community services. Also the Government is aware of the impact on a community of the kind of industrial development represented by the coal industry. The Government will encourage the improvement and growth of existing towns and facilities rather than the development of entirely new ones. It recognizes the weaknesses of "one-company" or even "one-resource" based communities and will promote economically feasible diversification wherever possible. The Government solicits the support of the coal industry in this regard and requests potential developers to propose projects which incorporate diversified activities. It agrees with the report of the Grande Cache Commission (Crump report) in recognizing that "reincarnation of the company town would ... be extremely unwise but the assumption of some of the financial risk of building the town by the compay might not be". ${ }^{130}$

The effect on townsites and infrastructures is always a prime concern of local residents when any major new coal mine or other industrial proposal is made for a location in proximity to what is usually a relatively small town. Oftentimes the majority of interventions at the E.R.C.B. hearing are concerned with matters of this nature. ${ }^{131}$ Frequently the E.R.C.B. hearing is used as a public sounding board and as a perceived communication conduit to the relevant government departments that have jurisdiction in regard to infrastructure matters. The only jurisdiction of the E.R.C.B. to hear these concerns falls within its general "public interest" mandate, as there is no specific legislation directing it to examine such issues. On the other hand, the Lieutenant Governor in Council has on occasion attached conditions to its approvals that require "the assumption of some of the financial risk of building the town by the company." 132

Unless it is a condition of a permit or approval, there are no legislated requirements for an applicant for a coal mine permit to provide assistance with development or expansion of infrastructure, such as schools, hospitals, and community services, other than by way of contributions through the existing property tax system. Recent examples of applicants undertaking to provide housing for workers have either been for planning reasons, for the development of the mine itself or at the request or admonition of the applicable government authorities. There is no express requirement for a mine applicant to provide such facilities.

A related problem arises due to the fact that coal mines are invariably located outside the boundaries of the local municipality which has to bear the brunt of housing and employee servicing costs required to enable construction and operation of the mine. This means that the sizeable prop-

130. Supra n. 1, s. 3.6.

131. See Obed Marsh Project, Application No. 790729, where seven out of twelve interven. tions emphasized the effect of the proposed coal mine on the local townsite and govern. ment infrastructure.

132. See the condition attached to Obed Marsh Project approval, O.C. 273/81:

The Permittee shall satisfy the Minister of Municipal Affairs, the Minister of the Environment, the Minister of Transportation and the Minister of Energy and Natural Resources, prior to December 31,1981, as to the plans of the Permittee with respect to

(a) transportation services to and from the proposed development.

(b) the housing of employees, and

(c) the development of additional necessary infrastructure. 
erty taxes arising from such a major industrial undertaking are for the most part outside the grasp of the municipality. ${ }^{133}$

The government does not intend to promote the creation of new company towns which would involve large government expenditures for creation of infrastructure, such as roads, municipal servicing, water and sewage treatment plants. In relation to the coal industry, the town of Grande Cache undoubtedly provides the best example of the government allowing and assisting in the creation of such a new town. ${ }^{34}$ In addition to the government using its control of the permitting process as a means of discouraging new "one-company" or "one-resource" towns, development of such towns is also unlikely in view of the fact that governments are responsible for supplying the infrastructure for such a development and could simply refuse to supply these services to the mining operation, thus making it difficult and expensive to attract workers to the mine. ${ }^{135}$

\section{G. Transportation}

The Government recognizes the vital role of transportation in the marketing of coal and will continue to support industries' efforts with the railways and the Government of Canada to ensure that planning and development of rail capacity keeps pace with needs and that freight rates are realistic. While some extension and upgrading of existing roads, bridges and railways will be in. evitable, the Government believes that most of the desirable new developments can be approved for areas now reasonably well provided with transportation service. Where entirely new facilities are needed primarily for the use of a coal development, the Government would expect the developer to pay their full cost. In keeping with the concept of diversification of economic activity for improved stability of the towns which will serve the expanded coal industry, the transportation system will be developed having in mind diversified industrial growth. ${ }^{136}$

Currently the only method of transportation of coal outside of Alberta is by rail. Since the national railways fall under exclusive federal jurisdiction, the provincial government has little control over them, other than through financial contributions to the purchase of rolling stock or to actual rail lines (e.g. the Alberta Resources Railway), or representations it may make to the federal government. Significantly, the government has declined to offer the prospect of public financial contribution to rail line extensions to virgin coal areas similar to that which the Province of British Columbia has undertaken in northeastern British Columbia. The conclusion, therefore, is that in the field of rail transportation a coal

133. Except for the Industrial Tax Transfer Grant whereby contributions are made to the adjoining town or city from the pertinent municipal district, county or improvement district in which the development is located.

134. An interesting example of the opposite effect of a new coal mining proposal was the removal of the hamlet of Keephills due to the expansion of the Highvale mine.

135. In its 1973 review of the Alberta coal industry, Energy Resources Conservation Board, ERCB Report 74-E, Review Of The Alberta Coal Industry 1973 (March 1974) the E.R.C.B. had the following to say at 12-5:

From an overview of this study the Board also considers it necessary that closer attention be given to economic aspects of new coal developments. The Board recognizes that, in particular cases, major coal developments in the future may involve substantial Provincial commitments and expenditures by various levels of government and by private individuals, and that it would be in the public interest for the Government to have a reasonable assurance of the permanence and soundness of these investments. The Board believes that in such cases, it may be appropriate for the Lieutenant Governor in Council, under the provision of Section 24(1) of The Energy Resources Conservation Act, to request the Board to investigate the general economic feasibility of the proposed project and to advise the Government thereon. The requirement to provide a cost-benefit analysis is undoubtedly an outgrowth of this recommendation.

136. Supra n. 1, s.3.7. 
developer will have minimal involvement from the government of Alberta and the lack of legislation in this province reflects this absence of direct participation.

Freight rates for coal transportation are negotiated by the developer with either the Canadian National Railway or the Canadian Pacific Railway, both of which are governed by the federal Railway Act and the Canadian Transport Commission. ${ }^{137}$ The government of the Province of Alberta has given no legislative indication as to how it intends that "the transportation system will be developed having in mind diversified industrial growth".

The government has, however, made provision for road transportation in its coal approval process. If a proposed project involves hauling coal on public roads the proponent is required to submit with his coal mine permit application a transportation impact assessment pursuant to the Public Highways Development Act. ${ }^{138}$ The E.R.C.B. in its guide "How to Apply for Government Approval of Mining Activities in Alberta", has set forth the purpose and contents of a transportation impact assessment, ${ }^{139}$ but there are no regulations concerning its content. The Board itself does not appear willing to assume a leading role in road planning for a coal development. ${ }^{140}$

In addition, Part 7 of The Exploration Regulation ${ }^{141}$ provides for the protection of public roads during the exploration phase of coal development.

\section{H. Royalty on crown coal - taxes on freehold coal}

Alberta will levy a realistic royalty on all coal produced from Crown leases and will levy a property tax on coal contained in producing freehold properties.

A new schedule of royalties payable on all coal produced from Crown leases and used or marketed becomes effective July 1,1976. Barring any major disruption of the economy or action of another government having a major impact upon revenues to the producer, the Government will plan to continue the use of the basic formula without change for a ten-year period.

Under The Mines and Minerals Act royalty is payable at the discretion of the Crown in kind as a percent of the quantity of coal used or marketed or in dollars as a percent of the deemed value of the coal used or the revenue received from the coal marketed. Where the Government is satisfied with the conditions of sale arranged by a lessee for the lessee's share of production, the Government may not take its royalty in kind and may request the lessee to market the royalty share of production along with the lessee share.

To recognize the high expenditures which must be made by a developer before revenues are produced, there will be a "phase-in" period of $\$ 6$ months from the start of commercial operations dur. ing which the rate of royalty will be increased in steps from a low initial level to the normal level. The royalty will increase each 12 months over this period from 25 to 50 . to 75 and finally to 100 percent of the normal level.

The normal royalty rate will be determined by a formula designed to ensure a fair share of revenues both to the developer and to the Alberta Crown under any reasonably foreseeable com.

137. R.S.C. 1970, c. 234, as am..

138. R.S.A. 1970 , c. 295 , as am..

139. Supra n. 8 at 5-24:

Purpose of the TIA

The TIA is meant to provide the Government with information on

- any additional demand to be placed on existing roads

- the need to upgrade present roads

- the need for new transportation services

- any potential conflict between roads proposed by the applicant and existing or future public roads

- the proposed design of any junction or crossing of private and public roads.

140. See supra n. 52 at $17-6$ and supra $n .74$ at 6.7 et seq.

141. Alta. Reg. $423 / 78$. 
bination of investment level, operating costs, production levels and coal prices.

The formula will provide for a normal royalty rate which:

(a) will not seriously restrict the rate of return to the investor in viable projects when total revenues only marginally exceed costs.

(b) will provide the Crown with approximately a one-third share of the total revenue under circumstances where the total revenue sufficiently exceeds the costs to provide a rate of return to the developer adequate to stimulate further exploration and development, and

(c) will provide the Crown with an increasing share of the total revenue when the return to the developer exceeds the rate mentioned above.

Details of the formula are given in Appendix I.

To ensure that the people of Alberta receive appropriate revenue from those coal reserves which are privately held, the Government will act under the Freehold Mineral Taxation Act and, effective January 1, 1977 will levy a property tax on those coal resources which are generating revenues to their owners. The tax will be based upon an assessed value of freehold coal property. Details of the assessment procedure will be developed in the near future and presented in regulations. $^{142}$

When the coal policy was announced in 1976 , the new royalty structure was seen as one of the more significant weather vanes indicative of the directions the government of Alberta intended to take. Previously the royalty rates for coal were at a fixed rate per ton. ${ }^{143}$ In its 1973 "Review of the Alberta Coal Industry", ${ }^{14}$ the E.R.C.B. recommended higher royalty rates. The coal policy now provides for a sliding scale royalty which reaches significantly higher than what is provided for in British Columbia. ${ }^{145}$ In effect, the government of Alberta has put the coal industry on notice that it sees no particular reason for haste in development of the industry in Alberta. Undoubtedly the province's current resource revenues and economic benefits arising from the petroleum and natural gas sector mitigate against the necessity of a rapidly expanding coal industry.

The royalty structure is set forth in The Coal Royalty Regulations. ${ }^{146}$

142. Supra n. 1, s. 3.8. (emphasis in original).

143. Ten cents per ton.

144. Supra n. 135.

145. British Columbia's royalty rate is twenty-five cents per ton for thermal coal and $\$ 1.25$ per ton for metallurgical coal.

146. Originally Alta. Reg. 193/76, but the actual royalty schedule was changed by Alta. Reg. 232/78:

The rate of royalty for a month for all agreements granting coal rights shall be the greater of

(a) $5 \%$, or

(b) the rate calculated in accordance with the following equation:

$$
X=K\left(1-\frac{C}{R}\right)^{2},
$$

where

$\mathrm{X}$ is the rate of royalty payable expressed as a percentage of marketable coal and products obtained from coal,

$\mathrm{K}$ is the project factor for a coal project or new coal project as determined in accordance with the following equation:

$$
K=\frac{50}{1+\frac{C}{R}\left(0.30 \frac{I}{C}-1\right)}
$$

where

I is the annual investment allowance of a coal project or new coal project,

$C$ is the annual cost allowance of a coal project or new coal project, and

$R$ is the annual revenue from a coal project or new project.

but where "C" exceeds " $R$ ", "C" is deemed to be $1 . "$ 
One questions whether this royalty structure is as "realistic" and "fair" as the coal policy suggests it is. ${ }^{147}$

The government has given no indication as to whether it plans any significant changes in the royalty structure upon the conclusion of the ten year period it advised it was prepared to wait. To date the government has taken no royalty share in kind. ${ }^{148}$ Undoubtedly, at least part of the reason for inclusion of a provision allowing the taking of royalty in kind is the prospect of a constitutional struggle similar to that in which the federal and Alberta governments engaged over petroleum and natural gas revenue sharing.

The thirty-six month royalty phase-in is provided for in s. 3 of The Coal Royalty Regulations. ${ }^{149}$ In its application the royalty rate varies from a low of 5 percent to a maximum royalty of approximately 35 percent,

147. The actual royalty can be calculated as follows:

CALCULATION OF ROYALTY FOR

COAL PRODUCED FROM ALBERTA CROWN LEASES

1) CALCULATE - ANNUAL COST ALLOWANCE "C"

Operating Cost

Provision for Mine Closing

Indirect Costs

Ammortization of Capital Investment

Annual Cost Allowance " $\mathrm{C}$ "

2) CALCULATE - ALLOWED CUMULATIVE INVESTMENT "I"

Ammortization Base, Previous Year

Capital Additions

Inflation Adjustment

Less

Ammortization of Capital Investment

Plus

Provision for Working Capital

Allowed Cumulative Investment "I"

3) CALCULATE - ANNUAL REVENUE "R"

Total Revenue

Less

Ex. Mine Costs

Annual Revenue " $R$ "

4) CALCULATE - PROJECT CHARACTERIZING FACTOR "K"

$K=\frac{50}{1+\frac{C}{R}\left(0.30 \frac{I}{C}-1\right)}$

5) CALCULATE - ROYALTY "X"

$$
X=K\left(1-\frac{C}{R}\right)^{2}
$$

The government has published "Interin Guidelines for the Calculation of Crown Royalty and Other Products" (1 July 1976).

148. Supran. 146, s. 5, and supra n. 78, s. 31(4). Note, however, that there does not appear to be any Ministerial power to deem a market value ior royalty calculation purposes, as is the case with petroleum and natural gas.

149. Id. 
however, the Lieutenant Governor in Council has the power to reduce the coal royalty below 5 percent. ${ }^{150}$

The provisions of the Freehold Mineral Taxation Act are designed to effectively mimic the current crown royalty for coal produced from freehold coal reserves, however, no regulations in this regard have been developed to date. ${ }^{151}$

Coal production, the disposition thereof and the value of sales must be reported monthly to the Department of Energy and Natural Resources ${ }^{15 ?}$ and the E.R.C.B. ${ }^{153}$

\section{Opportunity for equity participation by Albertans}

The Government has recognized the need to provide individual Albertans with an opportunity to invest in the development of the Province's energy and natural resources through creation of the Alberta Energy Company. As a matter of principle it believes that Albertans should be able to participate in the equity ownership of such resource developments.

The Government expects that many Albertans would welcome the opportunity to invest in the growth of Alberta's coal industry either directly or through the Alberta Energy Company. Consideration will therefore be given to the degree to which a developer proposes to provide this opportunity and, for developments involving Crown leases, project approval will be conditional upon the manner and degree of equity participation available to Albertans. It is assumed that such equity participation would commence immediately following project approval and would share in both the risk and profit. ${ }^{154}$

The Lieutenant Governor in Council, in considering for approval a coal mine permit application, attaches importance to the opportunities for equity participation by Albertans. To date the government has appeared to examine each application on its merits and has given no indication as to any formalized level of Alberta equity participation that it wishes to see in Alberta coal projects. In the Luscar Sterco (1977) Ltd. Coal Valley operation, for example, the Alberta Energy Company holds a 25 percent equity participation. More recently Union Oil Company of Canada Limited and Rescon Coal Holdings Ltd. received a coal mine permit for the Obed Marsh Thermal Coal Project. Rescon is a private Alberta company and Union, a public company holding 90 percent of the project at the time of the issuance of the mine permit, was approximately 13 percent Canadian owned. The Alberta equity participation is therefore not known, although Union did advise it had undertaken to offer participation to Albertans. ${ }^{155}$

There has been no direct or indirect expropriation of coal reserves in place, nor granting of such to Albertans, the Alberta government, the Alberta Energy Company nor to any Alberta crown corporation. It would

150. Id, s. 3(6):

Where in his opinion it is necessary or desirable in the interest of conservation and the prevention of waste or the loss of recovery of marketable coal or products of the coal, the Lieutenant Governor in Council may by order

(a) prescribe a royalty payable with respect to the marketable coal or products of the coal that is less than the royalty that would otherwise be payable under these regulations, and

(b) prescribe the period in respect of which the order is to apply.

151. Although assessment procedures are set forth in Part III of The Mineral Rights Assessment Regulations, Alta. Reg. 357/73. A freehold mineral tax apparently used to be levied, but was discontinued due to the minimal government revenues recovered.

152. Supra n. 78, s. 31.1.

153. Supra 119, ss. 68 and 69.

154. Supra n. 1, s. 3.9.

155. Union Oil Company of Canada Limited, "Interim Report to Shareholders," (31 March 1981). 
appear that the government is following its assumption that Alberta equity participation would share in both the risk and the profit.

-In order to monitor the situation The Coal Conservation Act provides that if there is any change in ownership of a mine or of a coal processing plant, the E.R.C.B. must be notified. ${ }^{156}$

\section{J. Timing of developments}

The Government recognizes that it may not be in Alberta's best interests that each major industrial development proceed within the time frame which the developer proposes and that some Government adjustment of the scheduling of projects may be necessary in recognition of such factors as the market situation, the assurance that Alberta's own requirements for coal are met, the prevention of a peaking of demand for capital available for Alberta projects, the supply for manpower, services, materials and equipment available in Alberta and the availability of adequate infrastructure. For these reasons the Government will exercise an overall control on the time when major coal (and other) developments are permitted to proceed.

Should the Government find it desirable in the public interest to require the deferral of a proposed development meeting other requirements of this policy, lease rentals and work requirements on affected Crown properties would be suspended for the period of the deferral. ${ }^{152}$

The factors relevant to scheduling of projects as set out in the coal policy, for the most part are not reflected in any specific legislation or regulations. Presumably such factors would either be considered by the E.R.C.B. during the permitting process or by the Lieutenant Governor in Council prior to the approval of any permit. ${ }^{158}$ To date the government has not refused to approve a mine permit in order to delay a coal project for any of the reasons set forth in the coal policy. However, in the case of the proposed Dodds Roundhill coal development in 1976, the government did make its apprehensions known, which undoubtedly was a factor in the developer not proceeding with the project. ${ }^{159}$ As well, the E.R.C.B. has ruled on the timing of the development of the Sheerness, Genessee, and Keephills power projects, which in turn has affected the development of the mines supplying coal to these projects. ${ }^{160}$ Should a project be deferred, The Mines and Minerals Act ${ }^{181}$ permits the Minister to waive lease rentals and work requirements for the period of the deferral.

\section{K. Overall benefit to Alberta}

A fundamental feature of the Government's policy is that no coal development will be permitted to proceed unless in its overall economic and social impact it is clearly beneficial to Alberta. This will be ensured by requiring that any proposal for a significant coal development be supported by a detailed Cost-Benefit and Social Impact Analysis which will be assessed by the appropriate departments and agencies of the Government and finally by the Executive Council. The analysis and assessment will incorporate the results of an Environmental Impact Assessment and will evaluate and weigh all significant direct and indirect benefits against all significant direct and indirect costs or adverse effects. Consideration will be given not only to those costs and benefits which are measurable in dollars but also to the more subjective, social costs and benefits.

In order that consideration of proposals for development may proceed on a co-ordinated basis and that worthy projects will not be unduly delayed, an applicant for project approval will be required to file a Cost-Benefit and Social Impact Analysis, an Environmental Impact Assessment and a Development and Reclamation Plan simultaneously with the Technical Application under The Coal Conservation Act. The Environmental Impact Assessment and the Development and

156. Supra n. 53, ss. 15 and 26.

157. Supra n. 1, s. 3.10.

158. Quaere whether the Supreme Court of Canada's recent decision, supra n. 128, limits the jurisdiction of the E.R.C.B. or the Lieutenant Governor in Council to attach conditions in this regard?

159. Although the proposal actually predated the coal policy.

160. See addendum to ERCB-AE Report 79-AA, In the Matter of a Power Plant and Coal Mine at Genessee.

161. Supra n. 78, s. 12.1(1)d. 
Reclamation Plan will be reviewed by all concerned departments with the appraisal being coordinated by the Department of the Environment. The Department will also be responsible for considering the specific applications under the environmental legislation.

A ppraisal of the Cost-Benefit and Social Impact A nalysis will involve all concerned departments of the Government and the Energy Resources Conservation Board and will be co-ordinated by the Department of Energy and Natural Resources. ${ }^{162}$

The E.R.C.B. requires a cost-benefit and social impact analysis pursuant to its general purposes under s. 4 of The Coal Conservation Act. ${ }^{163}$ To date there are no regulations setting forth the contents of such an analysis, however, the government has published "Guidelines for the Preparation of a Cost-Benefit and Social Impact Analysis". ${ }^{184}$ The E.R.C.B. specifically addresses this document but it makes no decision on the matter; the Board only notifies the Department of Energy and Natural Resources as to its views on the entire cost-benefit and social impact analysis. ${ }^{165}$ There would appear to be no legal obligation on an applicant to "evaluate and weigh all significant direct and indirect benefits against all significant direct and indirect costs or adverse effects". ${ }^{160}$ Therefore determination of the adequacy of any such analysis is at the discretion of the particular body concerned with its review. Should the analysis be inadequate or should the development be found to not be clearly beneficial to Alberta, the Lieutenant Governor in Council could exercise his discretion and refuse to approve the mine permit.

The status of the cost-benefit and social impact analysis guidelines is not clear. Although they have no legislative sanction, a mine permit applicant can be requested to comply with the guidelines by the E.R.C.B.or the government. Should he not do so, the granting of a permit to the applicant may be placed in jeopardy. Conversely, the appropriate body has the administrative capability to ignore the guidelines should it feel that doing so is warranted. The issue can be contentious when an applicant is requested to include in his analysis data that he wishes to keep confidential from competitors, for example, mining costs. It does not appear that there is any impetus to give legislative sanction to the guidelines, even though a great number of these guidelines are currently applied without exception to all coal mine permit applications.

\section{Granting of rights to explore for coal}

Rights to explore for coal under public lands may be granted whether or not an applicant has the leasehold right to produce the coal from under the lands but will only be granted under conditions which will ensure no significant adverse environmental impact.

The right to enter on the surface of public lands is granted under The Public Lands Act; approval must be obtained from the Local Authority to use public roads or road allowances. Control of the actual exporation activity and all associated operations on public lands is exercised primarily through The Coal Conservation Act. The Geophysical Regulations (under various acts), and The Land Surface Conservation and Reclamation Act. The provisions of The Clean Air Act. The Clean Water Act, The Water Resources Act. The Forests Act 1971 and The Forest and Prairie Protection Act must also be complied with.

162. Supra n. 1, s. 3.11.

163. Supra n. 53.

164. Department of Energy and Natural Resources, "Guidelines for the Preparation of a Cost-Benefit and Social Impact Analysis" (September 1976).

165. Supra n. 8 at 7-6.

166. There is not even an express obligation to evaluate some of the benefits and costs. McIntyre Mines Ltd. did not submit any cost-benefit analysis for the expansion of its No. 9 mine nor did Forestburg Collieries Limited submit such in its 1978 mine expansion application. 
Rights to explore for coal under private lands (whether the coal is owned by the Crown or otherwise) may also be granted separately from the right to produce the coal. The right of entry to the surface must be negotiated with the surface owner. The actual exploration activity and associated operations in the field will be made subject to much the same control as on public lands. ${ }^{307}$

Under The Public Lands Act and its accompanying regulations ${ }^{168}$ licences of occupation, as well as mineral surface leases, miscellaneous leases and easement agreements, can all be acquired. However, for preliminary exploration purposes the Department of Energy and Natural Resources will issue a letter of authority to enter on public lands and no formal request for such a letter is necessarily required. The Minister also has the right to refuse to accept applications for entry onto specific public lands or to refuse to issue licences of occupation. ${ }^{169}$

Except for specified exceptions a licence to conduct exploration is also required. ${ }^{170} \mathrm{As}$ well, the exploration program must be approved and no equipment can be operated without an exploration permit. ${ }^{171}$ The exceptions where no exploration licence is required are set out in $\mathbf{s . 2}$ of The Exploration Regulation. ${ }^{172}$ Consent to explore must also be obtained from persons in occupation of the surface of the land. ${ }^{173}$ Exploration restricted areas have been created in which no exploration, including the drilling of holes, may be conducted. ${ }^{174}$ Other lands can also be removed from exploration potential pursuant to The Land Surface Conservation and Reclamation Act or pursuant to the designation of restricted development areas or water conservation areas. ${ }^{175}$

Where the method of exploration involves a surface disturbance, approval must be sought pursuant to Part II of The Regulated Coal Surface Operations Regulations. ${ }^{176}$ Application is made to the E.R.C.B., which in turn forwards it to the Exploration Review Committee of the Land Conservation and Reclamation Council. ${ }^{177}$ The Exploration Review Committee considers the application having regard to "the general and overall impact of the proposed exploration on the environment in relation to the Land Conservation Guidelines, the ability of the applicant to complete in a satisfactory manner the proposed exploration and any reclamation required in connection therewith, and the past performance of the applicant in respect of any prior exploration or development or reclamation conducted by him". ${ }^{178}$

For deeper drilling or major excavation, exploration approval must be obtained pursuant to Part II of The Coal Conservation Regulations. ${ }^{179} \mathrm{Ex}-$

167. Supra n. 1, s. 3.12.

168. The Public Lands Act, R.S.A. 1970, c. 297, as am.; The Public Lands Licence of Occupation Regulations, Alta. Reg. 201/58, and The Mineral Surface Lease Regulations, supra n. 110.

169. The Public Lands Licence of Occupation Regulations, Alta. Reg. 201/58, ss. 6(1) and 7(a).

170. Supra n. 78, s. 188.

171. Supra n. 8 at 3.2.

172. Supra n. 15.

173. Id, s. 3.

174. Id, s. 4.

175. Id, s. 5.

176. Supra n. 17.

177. Supra n. 17, s. 6 and supra n. 21, Part III.

178. Supra n. 21, s. 20(1).

179. Supra n. 119. 
ploration that may affect any water resources, such as overburden drainage, depressurization of basal acquifers or diversion of surface or sub-surface water, requires an exploration permit under The Water Resources Act. ${ }^{180}$

When coal leases are acquired by public tender and a bonus is paid, exploration expenditures which are part of an exploration program approved by the E.R.C.B. can be applied against the bonus until it has been totally refunded. ${ }^{181}$

\section{Classification of lands for coal exploration and development}

Having regard to the questions of environmental sensitivity, alternate land uses, potential coal resources and the extent of existing development of townsites and transportation facilities, the Government has classified Provincial lands into four categories with respect to coal exploration and development:

Category 1 in which no exploration or commercial development will be permitted. This category includes National Parks, present or proposed Provincial Parks, Wilderness Areas, Natural Areas, Restricted Development Study Areas, Watershed Research Study Basins, Designated Recreation Areas, Designated Heritage Sites, Wildlife Sanctuaries, settled urban areas and major lakes and rivers. These are areas for which it has been determined that alternate land uses have a higher priority than coal activity. Category 1 also includes most areas associated with high environmental sensitivity; these are areas for which reclamation of disturbed lands cannot be assured with existing technology and in which the watershed must be protected.

Category 2 in which limited exploration is desirable and may be permitted under strict control but in which commerical [sic] development by surface mining will not normally be considered at the present time. This category contains lands in the Rocky Mountains and Foothills for which the preferred land or resource use remains to be determined, or areas where infrastructure facilities are generally absent or considered inadequate to support major mining operations. In addition this category contains local areas of high environmental sensitivity in which neither exploration or development activities will be permitted. Underground mining or in-situ operations may be permitted in areas within this category where the surface effects of the operation are deemed to be environmentally acceptable.

Category 3 in which exploration is desirable and may be permitted under appropriate control but in which development by surface or underground mining or in-situ operations will be approved subject to proper assurances respecting protection of the environment and reclamation of disturbed lands and as the provision of needed infrastructure is determined to be in the public interest. This category covers the Northern Forested Region and eastern portions of the Eastern Slopes Region shown in Map 1 of Appendix 2. It also includes Class 1 and Class 2 agricultural lands in the settled regions of the Province. Although lands in this category are generally less sensitive from an environmental standpoint than the lands in Category 2, the Government will require appropriate assurances, with respect to surface mining operations on agricultural lands, that such lands will be reclaimed to a level of productivity equal to or greater than that which existed prior to mining.

Category 4 in which exploration may be permitted under appropriate control and in which surface or underground mining or in-situ operations may be considered subject to proper assurances respecting protection of the environment and reclamation of disturbed lands. This category covers the parts of the Province not included in the other three categories.

Table 1 presents a summary of the classification system and the extent of exploration and development permitted in the four land categories. A further description of the Categories and two maps related to them are given in Appendix 2.

The Government emphasizes that the present classification, while based upon the best available knowledge, is subject to review in the light of changing knowledge and new technology related to environment protection, reclamation and mining methods. The Government will consider documented applications for reclassification of lands from any interested persons. Such applica. tions should be addressed to the Minister of Energy and Natural Resources with a copy to the Minister of the Environment.

It is also important to note that lands in Category 2,3 or 4 are not automatically open to exploration nor are lands in Category 3 or 4 automatically open to exploration and development. Each ap-

180. Supra n. 28.

181. See Energy and Natural Resources Information Letter 78-12. 
plication for rights to explore, for leases to Crown coal rights and for authorization for development will be considered on its own merits through the procedure outlined in Section 4.1,4.2 and 4.3. Particular care will be taken in the appraisal of applications for exploration or development in productive or potentially productive agricultural areas. ${ }^{182}$

The zoning system established by the coal policy is strictly internal to the Department of Energy and Natural Resources. No reference is made to it in any legislation or regulations. Administration and enforcement of the various zones centres on ministerial discretion. ${ }^{183}$ As well, the majority of the lands falling within Category 1 are governed by legislation which already gives the government the power to restrict development ${ }^{184}$ and the majority of all Category 2 lands are owned by the Crown as to both surface and mineral rights. Thus the government has the proprietary control necessary to implement the zoning system. The land use zoning in the coal policy also meshes closely with the zoning carried out under the

182. Supra n. 1, s. 3.13. Interestingly, the E.R.C.B. recital of the zoning policy in its Mining Guide (supra n. 8) has made slight changes to the explanation of the four categories.

183. E.g., The Mines and Minerals Act, supra n. 78, ss. 12 and 12.1:

S. 12 (1) The Minister may restrict the dispostion or withdraw from disposition any mineral in any specified area in any manner he may consider warranted.

(2) During the period that a mineral is withdrawn from disposition pursuant to subsection (1), no person has the right to acquire that mineral in all or any part of the area specified.

s.12.1 (1) The Minister may

(a) exchange any Crown minerals for other minerals in Alberta;

(b) acquire by expropriation any estate or interest in mines or minerals where the Minister is of the opinion that any or any further exploration for or development of those mines or minerals is not in the public interest:

(c) accept the surrender of, cancel or refuse to renew an agreement as to all or part of the location where the Minister is of the opinion that any or any further exploration for or development of the mineral to which the agreement relates within that location or part thereof is not in the public interest, subject to the payment of compensation determined in accordance with the regulations for the lessee's interest under the agreement;

(d) order the remission of all or part of any rental, fee or other sum payable under this Act, the regulations or an agreement, with or without conditions;

(e) where any provision of this Act, the regulations or an agreement requires the doing of any act within a fixed period or at a fixed time, by order, with or without conditions, extend that period or fix another time by or on which that act is to be done, whether the period within which or the time by or on which the act ought to be done has or has not expired or arrived, as the case may be;

(f) where he receives evidence satisfactory to him that a lessee has been prohibited by circumstances beyond the lessee's control, other than financial circumstances, from conducting operations on his location, from time to time agree with the lessee to extend the term of the lessee's agreement for an additional period or periods not exceeding 5 years in the aggregate upon any condition specified by the Minister in the case of any extension;

(g) reinstate upon such terms and conditions he may prescribe, an agreement, a part of the location of an agreement or a zone in the location of an agreement, that has been surrendered, cancelled or forefeited, if application for the reinstatement is made

(i) within 30 days of the date of the surrender, cancellation or forefeiture, or

(ii) within 90 days of the date of the surrender, cancellation or forfeiture, where the surrender, cancellation or forfeiture was made in error;

(h) where he considers that the circumstances warrant it, agree with a lessee to grant an agreement to the lessee in substitution for an agreement held by the lessee.

(2) Within 60 days of the completion of an exchange under subsection (1), clause (a), the Minister shall cause to be published in the Gazette a notice stating the particulars of the exchange and the reason for the exchange.

184. E.g. The Wilderness Areas Act, S.A. 1971, c. 114, as am.; and The Provincial Parks Act, S.A. 1974, c. 51. 
Eastern Slopes Policy. ${ }^{185}$ Coal leases in Category 4 lands are presently available for disposition. ${ }^{186}$

Since the zoning system is not legislated, the appeal procedures set out in the coal policy are handled administratively. Questions such as who might be an interested person, what might be the consequences of an "unfair" administrative rejection of an appeal, or what were the original reasons for the particular zoning, ${ }^{187}$ would therefore not seem to be answerable or reviewable by resort to the courts. The E.R.C.B. has, however, set out nine specific pieces of information required when any coal zoning appeal is taken. ${ }^{188}$

\section{N. Submission of results of exploration}

The Coal Conservation Act and regulations under it require the full submission to the Energy Resources Conservation Board of the results of exploration activity. This includes samples, cores, test data, surveys logs [sic] and other relevant data or information. These data are of vital importance in appraising the extent of Alberta's coal reserves. This information is kept confidential for a period of time and then becomes available to the public. ${ }^{189}$

The E.R.C.B.'s jurisdiction in this regard comes from s. 4(g) of The Coal Conservation Act. ${ }^{190}$ Part IV of The Coal Conservation Regulations sets out what is required to be submitted to the E.R.C.B. ${ }^{191}$ Data regarding the

185. Supra n. 2.

186. Supra n. 181.

187. E.g. the Government has admitted that one of the factors influencing the original zoning was the location of coal reserves that were known at the time.

188. Supra n. 8 at $2 \cdot 4$ :

Information Requirements for Applications for Reclassification of Lands Under the Coal Development Policy:

- A statement explaining the nature and purpose of the proposed reclassification.

- An overall statement of justification for the change, describing the economic and/or social benefits to the province should such a reclassification be approved.

- If a more protective classification is being requested, the applicant must submit sufficient background information to prove the significance of the area in both a regional and provincial context in order to justify the withdrawal of land and resources from future exploration or development.

- A statement of the exploration or development to take place including the reasons for selecting the particular site, the principal developer, a description of the specific activities to be undertaken on the land.

- A statement describing the timing of any exploration or development.

- A statement of present and possible land use conflicts, eg, timber, grazing, recreation, fisheries and wildlife, and how the conflicts will be resolved.

- A statement describing the known and foreseen environmental effects on the area, including impact on such things as water, soil, timber, vegetation and any measures that will be required to minimize any known or expected adverse effect.

- A statement describing the reclamation measures that will be taken when the activities are completed or terminated.

- A map(s) illustrating (scale - medium, eg. 1:50,000)

- the location of the proposed reclassification by Quarter section, Township, Range, and Meridian.

- the location of proposed and/or existing infrastructure such as roads, trails, and powerlines.

- details of Crown leases and freehold coal lands ownership within the proposed exploration/mining area.

189. Supra n. 1, s. 3.14 .

190. Supra n. 53:

The purposes of this Act are ... (g) to provide for the recording, and for the timely and useful dissemination of data and information relating to exploration for coal and to the occurrence, reserves, quality, production, transportation, processing and use of coal in Alberta.

191. Supra n. 119, see also supra n. 8 at 3-13. 
location and drilling of exploratory holes is available to the public immediately, while the logs, core segments, etc. therefrom are not available until two years from completion of the hole. ${ }^{192}$ Data from infill holes are kept confidential for five years. ${ }^{193}$ Special tests submitted to the Board are kept confidential until the Board decides their release is in the public interest. ${ }^{194}$ However, an operator may request that all his exploration data be kept confidential. ${ }^{195}$ The Board may use confidential information for certain specified purposes. ${ }^{196}$ Certain information regarding surface disturbances must be submitted to the Land Conservation and Reclamation Council upon completion of an exploration program. ${ }^{197}$

\section{0 . Restrictions on existing leases; lease purchase by the government}

The Government recognizes that the restrictions now imposed on exploration and development in the areas classified as Category 1,2 or 3 will affect persons holding Crown leases in areas in those categories and is prepared to purchase such leases for sums commensurate with expenditures which have been made with respect to them by the lessees. The Government requests holders of such leases in Category 1 to sell them back to the Government on this basis. Leases not sold will be subject to normal rental payments but will not be renewed on expiry of their terms.

Holders of Crown leases in Categories 2 and 3 may also sell their leases back to the Government. Alternately, they may continue to hold them on payment of normal rentals, recognizing the restrictions on development, and may expect them to be renewed on application.

Where the Government buys back Crown leases in areas in Categories 1,2 or 3 it will do so on the basis of approved expenditures, adjusted to a current dollar basis, plus interest.

Where freehold rights to coal and leases of such rights are affected by the restrictions on exploration and development imposed by Categories 1,2 and 3 , the Government is prepared to purchase the lessor rights on the same basis as for lessees of Crown rights.

Where the Government purchases leases as described above the results of any exploration work done on the leases will immediately be released to the public. ${ }^{190}$

The buy-back is accomplished pursuant to s. 12.2(1) of The Mines and Minerals Act. ${ }^{199}$ The amount of compensation is determined in accordance with The Mineral Rights Compensation Regulation. ${ }^{200}$ Bonus application fees, rentals, exploration and development costs, plus interest for up to ten years, are all included in this compensation. ${ }^{201}$ Since the regulations are phrased in the imperative it appears that the Minister is obligated to pay these amounts. Any party who has a lease repurchased or cancelled

192. Supra n. 119 , ss. 53 and 54.

193. Id., s. 55.

194. Id. s. 59.

195. Id., s. 16.

196. Id., s. 63:

(1) Notwithstanding the provisions of this Part, the Board may use confidential information for the purpose of preparing reports, maps and supporting information which it may from time to time publish.

(2) Where the Board uses confidential information in accordance with subsection (1) the report, map or supporting information shall be confined to

(a) delineation of the field or deposit,

(b) indication of its general geological identity, configuration, size, direction, and degree of dip,

(c) disclosure of the Board's estimate of reserves,

(d) in the case of a near surface coal deposit. qualitative notation that the reserves are considered to be recoverable by stripping, and

(e) in the case of coal recoverable by underground methods, the average depth at which the coal lies.

197. Supra n. 17, Part 6.

198. Supra n. 1, s. 3.15.

199. Supra n. 78.

200. Alta. Reg. $161 / 78$.

201. Id., s. 2. 
also acquires a right of first refusal should the government decide to reissue the lease at some future date. ${ }^{202}$ The Lieutenant Governor in Council may authorize the purchase of mineral rights in order to prevent environmental degradation or "inconsistent" use of land. ${ }^{203}$ The government has stated that it would be willing to buy back any affected Crown leases if it rejects a development proposal at the preliminary disclosure stage ${ }^{204}$ However, it is not obligated to do so and it seems that there would be instances of rejection at the preliminary disclosure stage where the government would not offer to buy back the affected Crown leases, for example, if it was rejected by reason of failure of the applicant to comply with an approval requirement. In fact, in no instances would it appear that the government is obligated to buy back leases; its only obligation is to pay certain amounts once it has decided to repurchase the leases. The Mineral Rights Compensation Regulations, ${ }^{205}$ in determining compensation, make no provision for an adjustment to a current dollar basis, as was the stated intention under the coal policy.

\section{P. Granting of leases for development}

About 80 percent of the coal resources of Alberta are owned by the Crown in the right of Alberta. The remaining privately owned 20 percent are located mainly in the central and southern settled regions of the Province.

Leases of Crown coal rights granting the right to produce the coal (subject to all applicable regulatory requirements) are issued under the provisions of The Mines and Minerals Act; such leases have an initial term of 21 years and require payment of an annual rental of $\$ 1$ per acre per year.

The Government has recognized that the leasing of Crown coal rights must accord with general land use and resource development policies applicable to all public lands in Alberta. Consequently since June, 1973 Crown coal leases have not been granted in areas such as the Eastern Slopes where long-term resource development policies have been under review. Elsewhere in the Province, leases of Crown coal rights have been granted only after review by an interdepartmental referral committee, and only in areas where it seems likely that exploration and development activities can meet strict environmental protection and reclamation standards.

In keeping with this policy, new coal leases will be granted only in areas where a reasonable likelihood exists that commercial mining operations will be permitted in the foreseeable future, subject to normal approval and regulatory procedures. Time-dated applications for new leases in Category 2 or 3 lands will be received and given preference in the order of receipt if and when the lands are reclassified as Category 4 or a specific development is approved. The possible need for the issuance of exploration permits will be considered...

New leases and renewals will be issued for initial or renewal terms of 15 years. The right of lease renewal will be assured to lease holders who commence or receive approval for commercial development. This will apply to all leases covered by the project approval. New leases and renewals will be subject to annual rental payments at the present rate of $\$ 1$ per acre, but holders of them may be required to conduct satisfactory programs of detailed reserves appraisal unless commercial operations are underway. The results of the appraisal would be submitted both to the Department of Energy and Natural Resources and to the Energy Resources Conservation Board. ${ }^{200}$

Crown coal leases, as well as being subject to the terms specifically included in the document, are also subject to the provisions of The Mines and Minerals Act. ${ }^{207}$ For anything but Category 4 lands, the Department

202. Id, s. 8.

203. Supra n. 75, s. 14:

The Lieutenant Governor in Council upon the recommendation of the Minister, may authorize the Minister of Energy and National Resources to acquire by expropriation any estate or interest in mines or minerals within, upon or under any land to prevent the environmental degradation or inconsistent use of that land as a result of the exploration for or recovery of those mine or minerals.

204. Supra n. 8 at 4-5.

205. Supra n. 200.

206. Supra n. 1, s. 3.16.

207. Supra n. 78. 
of Energy and Natural Resources currently accepts applications for leases and time dates them, but does not issue coal leases. Where there is more than one interested party for a particular acreage, the Department has the discretion to lease the mineral interest by public tender. ${ }^{208} \mathrm{It}$ is not known whether the practice of time dating coal lease applications would give any party a priority right to the actual coal leases. The Minister, it seems, would still have the discretion to issue a particular coal lease to a party who was not the first to apply for it. In spite of the coal policy assurance of a renewal of leases in approved commercial developments, the government is under no obligation to renew coal leases.$^{209} \mathrm{On}$ the other hand, a coal lease purports to grant the right to the coal that is the property of the Crown and not merely the right to produce the coal, as is usually the case with Crown mineral grants. ${ }^{210}$

No syndicate or other association of persons can acquire a lease in the name of that association unless it has been incorporated by or under an Act of the Province and approved by the Minister as an association that may hold the lease. ${ }^{211}$ The Crown Mineral Disposition Review Committee established under Part II of The Land Conservation Regulations, prior to the disposition of any Crown mineral rights, reviews the surface of the lands and the lands adjacent thereto having regard to the nature of the proposed disposition and its effect or possible effect on the environment and subsequently recommends granting of the lease or refusal. ${ }^{212}$

\section{Q. Regulation to ensure safe and efficient development without waste}

In addition to ensuring against adverse environmental impact the Government, through the provisions of The Coal Conservation Act and The Coal Mines Safety Act, and regulations, orders, permits and licences under them, will ensure that all coal mining and processing operations are carried out with full regard for safety and industrial health, efficiency, and the maximum practical recovery without waste of the coal resources being tapped.

Proper operations are ensured not only by the requirements of regulations and orders and the conditions of permits and licences but by actual field inspection by trained personnel of the Energy Resources Conservation Board. These inspectors co-operate with personnel of the Department of the Environment and Energy and Natural Resources to ensure compliance with conditions relating to the protection of the environment and of the renewable resources. ${ }^{213}$

Pursuant to The Coal Conservation Act, the E.R.C.B. is to ensure the orderly, efficient and economic development of Alberta's coal resources in the public interest, to effect conservation and prevent waste of the coal resources of Alberta and to ensure the observance of safe and efficient practices in exploration for, mining, storing, processing and transporting coal. ${ }^{24}$ In addition to the E.R.C.B. approval required to construct a mine and processing plant, ${ }^{215}$ licenses are required from the E.R.C.B. to actually operate the mine and processing plant ${ }^{216}$ and any facilities directly con-

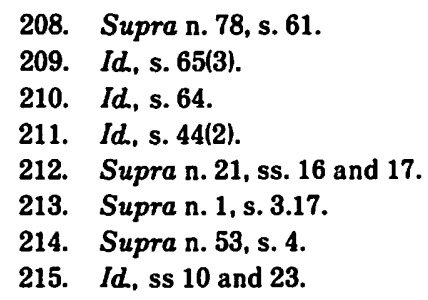

216. Id. ss. 11 and 23. The Board has a practice of licensing mines for the life of the pit or five years, whichever is less. They are generally renewed upon application if operation during the previous license period satisfies the Board in matters affecting safety and resource conservation. Supra n. 89 at 12-1. 
nected with the coal processing plant. ${ }^{217}$ If the Board feels that coal is not being recovered in accordance with good conservation practices and that it could be more efficiently recovered by other practical and reasonable mining or processing procedures, it may direct the holder of a permit, licence or approval to alter his program of development or operations accordingly. ${ }^{218}$ The Board also has a more general jurisdiction to effect conservation under the Energy Resources Conservation Act. ${ }^{219}$ In addition, the Lieutenant Governor in Council can reduce the Crown royalty where in his opinion it is necessary or desirable in the interests of conservation and the prevention of waste or the loss of recovery of marketable coal or products of coal. ${ }^{220}$ Finally, the E.R.C.B. has an ultimate jurisdiction to make such orders and to attach such conditions to approvals as it feels necessary to effect the purposes of The Coal Conservation Act. ${ }^{221}$ The Supreme Court of Canada has recently attempted to delineate the limits of this jurisdiction. ${ }^{222}$

As for safety in the minesite, Part IV of The Coal Mine Safety Regulations ${ }^{223}$ sets out what has to be done in this regard. The Department of Labour now has jurisdiction over coal mine safety. New equipment, new blasting techniques, the location and use of explosives and detonators, magazines, man riding procedures, battery charging stations, diesel garages, and notice of commencement of operations all require approval. ${ }^{224}$

\section{R. Efficient use of coal in Alberta - maximum upgrading}

In order to secure maximum benefit to Alberta from coal mining and processing activity. Government policy will require that so far as practical and beneficial to the Province, processing for the purpose of upgrading coal or any coal or any coal product to market specifications be undertaken in Alberta. This policy will apply to all types of coal as well as to secondary processing of all major products that are or may in future be obtained from coal by gasification, liquefaction or other forms of treatment.

The extent of processing that should be undertaken in Alberta in connection with any particular development will be assessed under the provisions of The Coal Conservation Act, having regard both for market opportunities and for all relevant environmental, technical, economic and social aspects of the proposals. The Energy Resources Conservation Board will determine to what extent potentially useful by-products from any project, if not immediately saleable, should be stockpiled and conserved for future marketing.

Except for the general purposes of The Coal Conservation Act, ${ }^{226}$ there are no legislative requirements for upgrading of coal in Alberta. The application of this portion of the policy falls under the administrative discretion of the E.R.C.B. and the Lieutenant Governor in Council.

217. Supra n. 53, s. 23(d).

218. Id; n. 47, s. 41.

219. Supra n. 148, ss. 2(c) and (e).

220. Id., s. 3(6).

221. Supra n. 53, s. 7:

The Board, with the approval of the Lieutenant Governor in Council, may make such just and reasonable orders or directions as may be necessary to effect the purposes of this Act but are not otherwise specifically authorized by this Act.

222. Supra n. 128.

223. The Coal Mines Safety Regulations, Reg. 333/75, as am..

224. Supra n. 8 at 8-11.

225. Supra n. 1, s. 3.18.

226. Supra n. 53, ss. 4(c) and (d). 


\section{S. Appraisal and protection of Alberta's requirements}

The protection of a supply of coal of suitable quality and suitably located which may be recovered at reasonable cost and which is adequate for Alberta's present and all foreseeable fut ure needs will be assured. This applies to requirements for present and future thermal power plants: future metallurgical operations; future other industrial requirements including petrochemical operations; future surface and in-situ gasification operations; and future coal liquefaction operations.

The protection will be assured under the provisions of The Coal Conservation Act by the Energy Resources Conservation Board through periodic assessments of Alberta's coal requirements made following pubic hearings and continuing appraisals of the proved and available reserves of coal in each of its major types. The Board will also ensure that the most appropriate deposits, having regard for location and costs, are made available for the generation of electric energy for $A$ lberta. Permits for mining developments to serve markets outside Alberta will only be granted where it is found in the public interest, having regard to the present and future requirements for coal in Alberta.

If for the protection of Alberta's future requirements it should be found necessary to deny a proposed earlier development meeting other requirements of this policy, lease rentals and work requirements on affected Crown properties would be suspended until development was authorized. 22

The E.R.C.B. carries out its periodic assessments of Alberta's coal requirements pursuant to section $4(\mathrm{~b})$ of The Coal Conservation Act. ${ }^{228}$ There are numerous requirements for operators to supply the E.R.C.B. with coal reserve information and data. ${ }^{223}$

Part 5.1 of The Coal Conservation Act sets out the details and necessity of obtaining an industrial development permit when coal is used as a raw material, reductant or fuel in any industrial or manufacturing operation. Small manufacturing operations and the production of electrical energy are excluded from the requirement to obtain an industrial development permit. No permit will be granted unless the Board determines that it is in the public interest to do so having regard to, among other considerations, the efficient use without waste of coal or products derived from coal and the present and future availability of coal in Alberta. ${ }^{230}$

The Board may, when requested to do so by the Lieutenant Governor in Council or upon its own motion, enquire into, examine, and investigate any matter referred to in $\mathbf{s . 4}$, the purposes section of The Coal Conservation Act. ${ }^{231}$ It may also hold an investigation into any matter connnected with the development and operation of a mine site, mine coal processing plant and connected facilities. ${ }^{232}$ Finally, it may make enquiries and investigations and prepare studies and reports on any matter within the purview of any Act administered by it relating to energy resources and energy, and recommend to the Lieutenant Governor in Council such measures as it considers necessary or advisable in the public interest related to the exploration for, production, development, conservation, control, transportation, transmission, use and marketing of energy resources and energy. ${ }^{233}$ It can be seen that the E.R.C.B. has wide ranging

227. Supra n. 1, s. 3.19 .

228. Supra n. 53:

The purposes of this Act are ... (b) to provide for appraisals of coal requirements in Alberta and in markets outside Alberta.

229. E.g. supra n. 53, s. 30 and supra n. 119, ss. 65 to 69.

230. Supra n. 53, s. 27.1(5); see also D. J. Jenkins, "Industrial Development Permits" (1979) 17 Alta. L. Rev. at 467.

231. Supra n. 53, s. 8.

232. Id., s. 40.

233. Id. s. 24. 
inquisitorial and investigative powers in regard to energy in general and coal in particular.

\section{T. Supply for Canadian markets beyond Alberta}

The Government recognizes that Alberta's coal resources will play an increasing important [sic] role in meeting essential energy demands in other parts of Canada. The Government will therefore be prepared under the provisions of The Coal Conservation Act to consider proposals for development of new coal mining and processing facilities that may from time to time be needed in order to help meet Canadian demands.

Developments to meet Canadian markets beyond Alberta will be authorized only if they meet all normal requirements, are in the Alberta public interest and provided that they are compatible with the protection of Alberta's present and future requirements.

To ensure stability of supply and avoid unduly rapid depletion of a particular grade of coal, or of a particular coal deposit, preference may be given to projects designed to produce and market an appropriate blend of different coals. ${ }^{24}$

There does not appear to be any specific legislative implementation of the government's concern regarding coal required to help meet Canadian demands. It is difficult to envision how the province could enact any such provisions without running the danger of overstepping the bounds of its provincial jurisdiction under the British North America Act. ${ }^{235}$ On the other hand, from 1928 to 1971 federal subvention aid was used to offset part of Alberta coal production and transportation costs and so enable Canadian coal to compete against imported fuels in central Canadian markets. ${ }^{236}$ To date there has been no practical experience with production and marketing of blends of different coals and the existing law does not reflect the stated government preference for such projects.

\section{U. Supply to foreign markets}

Where it appears to be in the Alberta public interest, the Government will consider proposals for new coal mining and processing development from which thermal and metallurgical coal can be supplied to foreign markets under suitable contractual arrangement. These will be considered under the provisions of The Coal Conservation Act.

Developments for foreign markets will also have to meet all normal requirements as described elsewhere and be compatible with the protection of Alberta's present and future requirements. ${ }^{237}$

It is interesting to note that the federal government to date has not enacted any legislation requiring government or National Energy Board approval of coal exports out of the country. What the Alberta government therefore approves and dictates through its various approval processes is the sole regulating factor for exports of Alberta coal out of the country.

\section{Pricing and marketing}

It is not the Government's intention at this time to intervene in prices or other marketing arrangements determined by contract between the producer and buyer of coal, provided they are compatible with overall government policy and the provision of applicable legislation, regulations and orders. The Government will however require that provision be made, in all future contracts for the sale of coal for delivery outside the province, for price review and possible redetermination at two-year intervals. The Government will arrange for a regular confidential monitoring by the Department of Energy and Natural Resources or the Energy Resources Conservation Board of the prices of coal sold under contract for markets outside Alberta. Should a situation develop where in the Government's view a fair price is not being received for coal shipped from Alberta, the Govern. ment will intervene as appropriate. ${ }^{230}$

234. Supra n. 1, s. 3.20.

235. (U.K.) 30 Vict., c. 3.

236. Supra n. 135 at 2-8.

237. Supra n. 1, s. 3.21.

238. Supra n. 1, s. 3.22. 
True to its word, the government has not intervened in prices and marketing arrangements. But it also has not insisted that all contracts for the sale of coal for delivery outside the province include price review and redetermination provisions at two year intervals. ${ }^{239} \mathrm{~A}$ mine operator is obliged to report to the E.R.C.B. monthly raw coal production, disposition and the value of sales for each month. ${ }^{240}$ However, the Board is required to keep confidential specific references to costs of production or processing and pricing. ${ }^{211}$ When the government speaks of intervening if a fair price is not being received, it is probably referring to the Crown's right to take its royalty share in kind. ${ }^{242}$ However, in view of the wide discretionary powers of both the government, through the Department of Energy and Natural Resources, and the E.R.C.B., there is virtually an unlimited number of other steps that it could take. As part of the technical mine permit application, the E.R.C.B. requires a general statement concerning marketing plans. ${ }^{243} \mathrm{~A}$ typical example of the government's current thinking is the condition attached to the Obed-Marsh project approval that the permittee: 244

satisfy the Minister of Energy and Natural Resources that, at least six months prior to the date of start up of production, the price of any coal sold for use outside Alberta is generally compatible with the prices paid for similar types and qualities of coal used in Canada and elsewhere, and that appropriate provision has been made for the review and redetermination of prices in each contract for the sale of coal.

\section{W. Manpower training}

In order to enable Albertans to avail themselves of employment and career opportunities in coal exploration and development activities, and to alleviate potentially serious shortages of qualified manpower the Government will keep itself informed on the projected manpower needs for the industry and take such measures as may be required to assure the adequacy of training facilities.

The Government will expect the coal industry and related enterprises to develop or expand on-the-job training programs and to afford employees suitable opportunities of skill-upgrading programs. $^{245}$

The government has not enacted any specific legislative requirements in regard to on-the-job training and skill upgrading programs in the coal industry.

\section{$\mathrm{X}$. Research and development}

The Government recognizes that efficient development and use of Alberta's coal resources will depend on continued and increased research and on the exchange of scientific and technical information with the coal industry and government agencies elsewhere.

To help generate up-to-date information on the location, extent and characteristics of Alberta's coals, and to assist the development of new or improved technologies for extracting, processing, transporting and using the various kinds of coal found in the province, the Government will therefore continue to support resource appraisal programs by the Energy Resources Conservation Board and coal-related research projects at the Alberta Research Council. Through detailed discussions with industry, the Government will also assess what additional in. vestigations and test facilities may from time to time be required to meet Alberta's needs and, where desirable, participate in specific studies and in the establishment of additional facilities.

239. Export coal contracts have been signed that do not provide for biannual price reviews.

240. Supra n. 119, ss. 68 and 69.

241. Id., s. 61.

242. Supra n. 148.

243. Supre n. 8 at 5-8.

244. O.C. $273 / 81$.

245. Supra n. 1, s. 3.23 . 
The Government will take steps to ensure that Alberta is an active party to current and future international technology exchanges, and that relevant scientific and technical advances made elsewhere are available for detailed assessment and possible use in Alberta. ${ }^{240}$

Except for the information gathering and resource appraisal powers within the jurisdiction of the E.R.C.B., ${ }^{247}$ the government has not enacted any research and development legislation specifically concerning the coal industry.

\section{CONCLUSION}

The province of Alberta currently has in effect a comprehensive regulatory regime governing the coal industry. Prime responsibility for managing this regime lies with the Department of Energy and Natural Resources and the Energy Resources Conservation Board, and to a lesser extent the Department of the Environment. The focal point of the approval process is the mine permit application and hearing before the E.R.C.B., although ultimate responsibility for any major project lies with the Lieutenant Governor in Council.

It also can be seen that the government has basically chosen a method of administrative control of the industry through the Alberta public service and the executive branch. This decision is probably grounded on a number of factors, notably the historical development of our system of government, political ideology, the newness and potential for expansion of the coal industry in Alberta, the rapidly changing state of the art of coal technology, and the consequently perceived requirement for administrative flexibility and government intervention. As a result of this the industry, although highly regulated by government, is not based upon any cohesive set of legal rights; it is therefore "administered", rather than "regulated" in a legal sense.

On the other hand, in emphasizing the "one window" approach centered around the required E.R.C.B. hearing, and in directing that a number of other required approvals be examined at that hearing, ${ }^{248}$ the Alberta regime has to a great extent established both the proponent's and the public's "right" to have decisions on the project made openly. The salient aspects of any new coal development cannot escape public scrutiny and debate in the E.R.C.B.'s forum.

Unfortunately, the openness of the real decision making may be more perceived than actual, in view of the E.R.C.B.'s limited jurisdiction and the wide scope for ministerial and Lieutenant Governor in Council discretion. At law this discretion is so broad that it can vary or overturn almost any decision or recommendation made at or arising out of the public hearing. Such discretion is shielded from public examination since there are few, if any, methods of review of these decisions other than political redress by elections, and since no reasons for the use of the discretion need be given. It may be the inarticulated premise of the Alberta regime that because decisions in regard to the coal industry have such a major impact on the whole province, they must be dealt with in their entirety by the political process and only in limited areas, through and subject to our legal system.

246. Supra n. 1, s. 3.24.

247. E.g. supra n. 229.

248. E.g. The environmental impact assessment and cost-benefit and social impact analysis are to be complete and before the Energy Resources Conservation Board for the public hearing, even though the E.R.C.B. is not the assessing body. 